\title{
The RGSZ2 Protein Exists in a Complex with $\mu$-Opioid Receptors and Regulates the Desensitizing Capacity of $\mathrm{Gz}$ Proteins
}

\author{
Javier Garzón*,', María Rodríguez-Muñoz', Almudena López-Fando' and Pilar Sánchez-Blázquez' \\ 'Neurofarmacología, Instituto de Neurobiología Santiago Ramón y Cajal, CSIC, Madrid, Spain
}

The regulator of G-protein signaling RGSI7(Z2) is a member of the RGS-Rz subfamily of GTPase-activating proteins (GAP) that efficiently deactivate G $\alpha$ ZGTP subunits. We have found that in the central nervous system (CNS), the levels of RGSZ2 mRNA and protein are elevated in the hypothalamus, midbrain, and pons-medulla, and that RGSZ2 is glycosylated in synaptosomal membranes isolated from CNS tissue. In analyzing the function of RGSZ2 in the CNS, we found that when the expression of RGSZ2 was impaired, the antinociceptive response to morphine and $\left[\mathrm{D}-\mathrm{Ala}^{2}, \mathrm{~N}-\mathrm{MePhe}^{4}, \mathrm{Gly}_{-} \mathrm{ol}^{5}\right]$-enkephalin (DAMGO) augmented. This potentiation involved $\mu$-opioid receptors and increased tolerance to further doses of these agonists administered $24 \mathrm{~h}$ later. High doses of morphine promoted agonist desensitization even within the analgesia time-course, a phenomenon that appears to be related to the great capacity of morphine to activate Gz proteins. In contrast, the knockdown of RGSZ2 proteins did not affect the activity of $\delta$ receptor agonists, [D-Pen ${ }^{2,5}$ ]-enkephalin (DPDPE), and [D-Ala ${ }^{2}$ deltorphin II. In membranes from periaqueductal gray matter (PAG), both RGSZ2 and the related $\mathrm{RGS20}(\mathrm{ZI})$ co-precipitated with $\mu$-opioid receptors. While a morphine challenge reduced the association of $\mathrm{Gi} / \mathrm{o} / \mathrm{z}$ with $\mu$ receptors, it increased their association with the RGSZ2 and RGSZI proteins. However, only Gaz subunits co-precipitated with RGSZ2. Doses of morphine that produced acute tolerance maintained the association of G $\alpha$ subunits with RGSZ proteins even after the analgesic effects had ceased. These results indicate that both RGSZI and RGSZ2 proteins influence $\mu$ receptor signaling by sequestering G $\alpha$ subunits, therefore behaving as effector antagonists.

Neuropsychopharmacology (2005) 30, 1632-1648. doi:I0.1038/sj.npp. 1300726; published online I3 April 2005

Keywords: RGSZ2; G-protein signaling; mu-opioid receptor; desensitization; antisense technology

\section{INTRODUCTION}

The synchronization of $G$ protein-coupled receptors (GPCR) with their target effectors is dependent on G proteins and on the activity of specific regulators of $G$ protein signaling, the RGS proteins. These RGS proteins act as GTPase-activating proteins (GAP) that terminate $\mathrm{G} \alpha$ signaling by accelerating the hydrolysis of GTP to GDP. However, some RGS proteins are also responsible for attenuating and abbreviating the effects of opioid agonist (Garzón et al, 2001, 2003, 2005; Sánchez-Blázquez et al, $2003,2005)$. While the $\mu, \delta$, and $\kappa$-opioid receptors can activate the $\mathrm{Gi} / \mathrm{o}$ and $\mathrm{Gq} / 11$ proteins, the activation of $\mathrm{Gz}$ proteins is principally linked to $\mu$ receptor signaling

*Correspondence: Dr J Garzón, Neurofarmacología, Instituto Cajal, Consejo Superior de Investigaciones Cientíicas, Avd Doctor Arce, 37. E-28002 Madrid, Spain, Tel: 34 9l 585 4733, Fax: 34 9l 585 4754, E-mail: jgarzon@cajal.csic.es

Received 20 May 2004; revised 19 January 2005; accepted 24 February 2005

Online publication: I March 2005 at http://www.acnp.org/citations/ NPP030 I 05040233/default.pdf
(Sánchez-Blázquez et al, 1995; Standifer et al, 1996; Garzón et al, 1997a,b). Members of the RGS-R7 subfamily have been implicated in the attenuation of opioid signaling and this may occur through the sequestration of $G \alpha$ subunits (Garzón et al, 2005). This non-GAP RGS activity prevents these subunits from acting on effectors or binding to $G \beta \gamma$ dimers to reconstitute $\mathrm{G}$ proteins. Moreover, hydrolyzation of GTP bound to G $\alpha z$ subunits may also attenuate the effects of agonists. This is because while $\mathrm{G} \alpha \mathrm{i}$ and $\mathrm{G} \alpha \mathrm{o}$ subunits hydrolyze bound GTP with a $t_{1 / 2}$ of about $10-20 \mathrm{~s}$, this process is extremely inefficient for $\mathrm{G} \alpha \mathrm{z}\left(t_{1 / 2}=7 \mathrm{~min}\right.$ ) (Casey et al, 1990; Wang et al, 1997). When the members of the RGS-Rz subfamily bind to G $\alpha \mathrm{zGTP}$, the hydrolysis rate increases by $200-400$-fold, allowing signaling to be terminated within a few seconds (Glick et al, 1998; Wang et al, 1998). Thus, unless RGS-Rz proteins promote the hydrolysis of GTP, activated G $\alpha z$ subunits are difficult to switch off after receptor activation.

The RGS-Rz subfamily includes RGSZ2, GAIP (G $\alpha$ interacting protein $=$ RGS19), and two alternative splice variants, RGSZ1 and retinal RET-RGS1 (Ross and Wilkie, 2000). Besides the RGS box and a short $C$ terminus of 11 or 
12 amino-acid residues, these proteins contain a heavily palmitoylated cysteine string motif at the $\mathrm{N}$ terminus that is involved in membrane targeting (De Vries et al, 1996). GAIP also has an amphipathic helix at the $\mathrm{N}$ terminus and a PDZbinding motif at the C terminus (De Vries et al, 1998; Ross and Wilkie, 2000). The RGSZ2 described by Jordan et al (1999) lacks the amphipathic helix at the $\mathrm{N}$ terminus and the C-terminal PDZ-binding motif present in GAIP, exhibiting closer homology to RGSZ1. The RGS-Rz genes are the most highly conserved RGS subfamily in metazoans, and one, two, or three copies of these RGS-Rz genes existing in flies, worms, and mammals, respectively (Sierra et al, 2002). Furthermore, it is noteworthy that the human and mouse RGS-Rz genes are closely linked to the opioid receptor genes. The RGSZ1, GAIP, and RGSZ2 genes are found close to the $\kappa$ (opioid-like receptor 1 ), ORL1, and $\mu$-opioid receptor genes, respectively, suggesting that these pairs of genes can be coordinately expressed (Sierra et al, 2002). In fact, the GAIP and ORL1 genes lie head to head and share promoter elements (Ito et al, 2000), indicating that the physical linkage between these GPCRs and RGS-Rz proteins may play a significant role in the regulation of their signaling.

In the central nervous system (CNS), Gz proteins are more effective in mediating the desensitization of $\mu$-opioid receptors than Gi2 proteins (Garzón et al, 2004; SánchezBlázquez et al, 2005). Moreover, RGSZ1 regulates $\mathrm{Gz}$ proteins following their activation by $\mu$ receptors, as does GAIP, albeit to a much lesser extent (Garzón et al, 2004). These observations compelled us to investigate how RGSZ2 might regulate $\mu$ - and $\delta$-opioid receptors. As a result, we found that RGSZ2 co-precipitates with $\mu$-opioid receptors in the CNS, and that it plays an important role in controlling G $\alpha$ z-mediated opioid desensitization.

\section{METHODS}

\section{Downregulation of RGSZ2 Expression}

Two synthetic end-capped phosphorothioate (indicated as *) antisense oligodeoxynucleotides (ODNs) were designed (PrimerSelect, DNASTAR Inc., Madison, WI, USA) and the following ODN sequences were prepared (Sigma-Genosys Ltd, Cambridge, UK): ODN1: $5^{\prime}-\mathrm{T}^{\star} \mathrm{T}^{\star} \mathrm{TGTGACTGCTGC}$ $\mathrm{CG}^{*} \mathrm{~T}^{\star} \mathrm{T}-3^{\prime}$ corresponding to nucleotides 148-165 and ODN2: $5^{\prime}-\mathrm{C}^{\star} \mathrm{C}^{\star}$ GAAGAGTCTCCTC ${ }^{\star} \mathrm{T}^{\star} \mathrm{T}-3^{\prime}$ corresponding to nucleotides 281-297 of the murine RGSZ2 gene (NM_019958). These sequences show no homology to other cloned proteins described in this species (GeneBank database). As a control, antisense ODNs containing five mismatched bases were also generated: ODN1-RGSZ2M, $5^{\prime}-\mathrm{T}^{*} \mathrm{~T}^{\star}$ AGTCAGTGCAGCGG ${ }^{*} \mathrm{~T}^{\star} \mathrm{T}-3^{\prime}$ : ODN2-RGSZ2M $5^{\prime}-$ $\mathrm{C}^{\star} \mathrm{G}^{\star} \mathrm{GAACAGACTCGTC}{ }^{\star} \mathrm{A}^{\star} \mathrm{T}-3^{\prime}$.

These ODNs were injected into the lateral ventricle of animals lightly anaesthetized with ether as described previously (Sánchez-Blázquez et al, 1995; Garzón et al, 2000). Each series of ODN injections was performed on a distinct group of mice according to the following 5-day schedule: $1 \mathrm{nmol}$ on days 1 and 2, $2 \mathrm{nmol}$ on days 3 and 4, $3 \mathrm{nmol}$ on day 5. Functional studies were usually started on the 6th day, and the mice were monitored for horizontal and vertical activity over periods of $10 \mathrm{~min}$ (Digiscan animal activity monitor system, Omnitech electronics, Columbus, $\mathrm{OH}$, USA). Only ODNs that did not alter mouse motor performance were selected for further study. The absence of injury due to the ODNs used was checked routinely (Garzón et al, 2000, 2003).

\section{Expression of RGSZ2}

A cDNA clone of RGSZ2 was generated by PCR using mouse brain cDNA as a template (Platinum Pfx DNA Polymerase, Invitrogen Life technologies \#11708-013). The primers used corresponded to the $5^{\prime}$ and $3^{\prime}$ ends of the coding region and included an EcoRI or SalI restriction site: $5^{\prime}$-GAAGCAGC GAATTCGAGAAAACGGCAGCAGTCAC- $3^{\prime}$ and $5^{\prime}$-ACGCG TCGACTTAGGATTCAGAAGTACAGCTGG-3' (the start codon was supplied by the expression vector, the stop codon is underlined). A $629 \mathrm{bp}$ product was obtained and a glutathione $S$-transferase (GST) fusion protein of murine RGSZ2 (AF 191555) was generated by inserting the PCR product into the bacterial expression vector pGEX-4T-3 (Amersham Biosciences, \#27-4801) at the EcoRI and SalI sites. The vector was introduced into the BL21(DE3) Escherichia coli strain (Invitrogen, \#C6060, Groningen, The Netherlands) and protein expression induced with $0.1 \mathrm{mM}$ isopropyl- $\beta$-D-thiogalactoside (Amersham Biosciences, \#27-3054) for $3 \mathrm{~h}$ at $37^{\circ} \mathrm{C}$. The GST fusion protein was purified with glutathione-Sepharose 4B (Amersham Biosciences, \#27-4570) and cleaved with biotinylated thrombin (Novagen, \#69672-3, Madison, WI, USA). The thrombin was removed by binding to streptavidin agarose.

\section{Production, Purification and Characterization of Antibodies Against RGSZ2}

We synthesized the murine RGSZ2 peptide sequence NSQIYKAFVESTTS (amino acids 192-205; Sigma-Genosys Ltd, Cambridge, UK) that exhibits $<20 \%$ homology to other known protein sequences (EMBL, GenBank and SwissProt databases). The peptide included an N-terminal cysteine and was conjugated to keyhole limpet hemocyanin carrier protein using maleimidocaproyl- $N$-hydroxysuccinimide. Anti RGSZ2 IgGs were purified by affinity chromatography using the peptide coupled to NHS-activated Sepharose 4 Fast Flow (17-0906-01, Amersham Biosciences, Barcelona, Spain) according to the manufacturer's instructions. The full protocol has been described elsewhere (Garzón et al, 1995).

\section{Detection of Signaling Proteins in Mouse Brain by Immunoblotting}

Mice were decapitated and the brain structures from four mice were collected and pooled for each experiment. The SDS-solubilized synaptosomal membranes were resolved by SDS/polyacrylamide gel electrophoresis (PAGE) in $8 \mathrm{~cm} \times 11 \mathrm{~cm} \times 1.5 \mathrm{~cm}$ gel slabs $(10-20 \%$ total acrylamide concentration $/ 2.6 \%$ bisacrylamide crosslinker concentration) and for immunodetection, 40-60 $\mu \mathrm{g}$ protein of each neural structure (DC protein Assay, Biorad \#500-0116) was used. Equal loading was verified by probing the blots with an anti- $\beta$-actin antibody (CSA-400, Stressgen, Victoria, Canada), either in the same or parallel blots. The separated 
proteins were transferred to $0.2 \mu \mathrm{m}$ polyvinylidene difluoride membranes (Bio-Rad), and the membranes were incubated at $6^{\circ} \mathrm{C}$ for $24 \mathrm{~h}$ with polyclonal antisera diluted in TBS-0.05\% Tween 20 (TTBS): anti-G $\alpha$ o (GC/2, NEI-804) 1 : 1000; anti-G $\alpha z$, anti-G $\alpha \mathrm{i} 2$, and anti-G $\alpha \mathrm{i} 1$ (1:2000; Garzón et al, 1997a), as well as affinity-purified IgGs raised against RGSZ2 and RGSZ1 (1:3000; Garzón et al, 2004; SánchezBlázquez et al, 2005). Antibody binding was detected with a goat anti-rabbit IgG $(\mathrm{H}+\mathrm{L})$ horseradish peroxidase conjugate antiserum (BioRad, \#170-6515) diluted 1:5000 in TTBS and exposed to the membranes for $3 \mathrm{~h}$. The secondary antibody was visualized with the ECL plus Western Blotting Detection System (RPN2132, Amersham Biosciences), and chemiluminescence was detected using a Peltier cooled CCD camera $\left(-35^{\circ} \mathrm{C}\right.$; high signal-to-noise ratio; dynamic range up of $3.4 \mathrm{OD}$ ) and a ChemiImager IS-5500 (Alpha Innotech, San Leandro, California). This system provides a real-time readout (30 frames per second) that can be analyzed by densitometry (AlphaEase v3.2.2).

\section{Membrane Solubilization and Glycoprotein Purification by Wheatgerm Lectin (WGL) Affinity Chromatography}

Membrane solubilization and WGL affinity chromatography were carried out at $4^{\circ} \mathrm{C}$ as described previously (Garzón et al, 2004). Briefly, cerebral cortex membranes were solubilized in $2 \%$ Triton X-100 buffer and applied to a WGL-Sepharose 4B column (AmershamPharmacia Biotech, \#17-0444). The retained glycoproteins were then eluted with $\mathrm{N}$-acetyl-D-glucosamine.

\section{Deglycosylation of RGSZ2}

$\mathrm{N}$-glycosidase $\mathrm{F}$ assay. The glycoproteins were heated at $100^{\circ} \mathrm{C}$ for $10 \mathrm{~min}$ at $4 \mu \mathrm{g} / \mu \mathrm{l}$ in $100 \mathrm{mM} \mathrm{NaH}{ }_{2} \mathrm{PO}_{4}, \mathrm{pH} 7.7$, $1 \mathrm{mM}$ EDTA, $1 \% \quad \beta$-mercaptoethanol, $0.1 \%$ SDS, $1 \mathrm{mM}$ dithiothreitol. Afterwards, the mixture was supplemented with $0.65 \%$ octyltioglucoside to help remove the SDS from the proteins, and incubated with $N$-glycosidase F (1 U/10 $\mu \mathrm{g}$ protein; Roche Diagnostics, 1365 169, Mannheim, Germany) for $18 \mathrm{~h}$ at $37^{\circ} \mathrm{C}$.

$\mathrm{O}$-glycosidase assay. The glycoproteins were heated at $100^{\circ} \mathrm{C}$ for $10 \mathrm{~min}$ at $2 \mu \mathrm{g} / \mu \mathrm{l}$ in $100 \mathrm{mM} \mathrm{NaH}_{2} \mathrm{PO}_{4}, \mathrm{pH} 6.8$, $1 \mathrm{mM}$ EDTA, $1 \mathrm{mM}$ dithiothreitol, $0.5 \%$ SDS. Subsequently, $0.65 \%$ octylthioglucoside, EDTA $20 \mathrm{mM}$ were added to the glycoproteins, which were then incubated with $O$-glycosidase $(1 \mathrm{U} / 20 \mu \mathrm{g}$ protein; Roche, $1347 \mathrm{101})$ for $18 \mathrm{~h}$ at $37^{\circ} \mathrm{C}$.

\section{RT-PCR}

Total RNA was obtained by a single-step procedure (Ultraspec RNA isolation system, Biotecx Labs, Houston, TX, USA) and stored at $-80^{\circ} \mathrm{C}$ in RNA storage solution (Ambion, Austin, TX, USA). Using this procedure, RNA free of DNA contamination is obtained that is ready for use in RT-PCR without the need for additional DNase treatment (manufacturer's specifications). This was confirmed in routine assays with PCR performed without a prior RT step. For each neural structure analyzed, $2 \mu \mathrm{g}$ of total RNA was reverse transcribed with a oligo deoxythymidine primer using the RT-PCR First Strand Synthesis Kit (RETROscript,
Ambion) and cDNA synthesis was carried out at $42^{\circ} \mathrm{C}$ for $60 \mathrm{~min}$. PCR reactions were performed on $0.05,0.1$, and $0.2 \mu \mathrm{g}$ of total RNA in a final volume of $50 \mu \mathrm{l}$ of the buffer solution containing: $10 \mathrm{mM}$ Tris $\mathrm{HCl}(\mathrm{pH} 8.3), 50 \mathrm{mM} \mathrm{KCl}$, $1.5 \mathrm{mM} \mathrm{MgCl}_{2}, 125 \mu \mathrm{M}$ of each dNTP, $0.5 \mu \mathrm{M}$ of each primer, and $1 \mathrm{U}$ of SuperTaq thermostable DNA polymerase (Ambion). The cDNA primers used for the murine RGSZ2 gene (AF 191555) were: 5'-TCTCGCCCACATCTAAGTC TACCC-3' (bp 91-114; forward) and 5'-ATCATCCTGGCC TTTTCTTCAACA-3' (bp 524-547; reverse); yielding a product of $457 \mathrm{bp}$.

PCR amplification was performed over 31 cycles on a DNA Mastercycler (Eppendorf AG, Hamburg, Germany) using thin-walled $0.5 \mathrm{ml}$ PCR tubes (Ambion) and the following protocol: one cycle of $94^{\circ} \mathrm{C}(1 \mathrm{~min}) ; 30$ cycles of $94^{\circ} \mathrm{C}(20 \mathrm{~s})$ and $60^{\circ} \mathrm{C}(30 \mathrm{~s})$; and a final $3 \mathrm{~min}$ incubation at $72^{\circ} \mathrm{C}$. To confirm the identity of the cDNA amplified, the PCR products were separated in $2.5 \%$ agarose gels with PCR markers 80-1000 (Biotools) and then incubated in SYBR gold solution (Molecular Probes \#S-11494, Poortgebouw, Netherlands) for $20 \mathrm{~min}$. DNA products were visualized with UV light (ChemiImager IS-5500). The signals associated with RGSZ2 mRNA were normalized with those obtained by amplification of a segment of 179 base pairs GAPDH, internal standard.

\section{Incubation of $\mu$-Opioid Agonists with Synaptosomal Membranes of Mouse PAG}

Mouse PAG membranes enriched in synaptosomes were incubated with either GTP or the G $\alpha$-binding nondissociating nucleotide GTP $\gamma \mathrm{S}$, in the presence of morphine or [D$\mathrm{Ala}^{2}, \mathrm{~N}$-MePhe ${ }^{4}, \mathrm{Gly}^{-\mathrm{Ol}^{5}}$ ]-enkephalin (DAMGO). The GTP $\gamma \mathrm{S}$ was used at 0.5 and $30 \mathrm{nM}$ in a buffer that contained $50 \mathrm{mM}$ Tris-HCl, pH 7.4, $100 \mathrm{mM} \mathrm{NaCl}, 10 \mathrm{mM} \mathrm{MgCl}_{2}, 1 \mathrm{mM}$ EDTA, $1 \mathrm{mM}$ DTT, $30 \mu \mathrm{M}$ GDP, and $0.1 \%$ BSA. The assay was conducted at $25^{\circ} \mathrm{C}$ for $1 \mathrm{~h}$. The buffer used when incubating with GTP contained $1 \mu \mathrm{M}$ of the nucleotide, $0.1 \mathrm{mM}$ EDTA; $2 \mathrm{mM}$ dithiothreitol; $100 \mathrm{mM} \mathrm{NaCl} ; 5 \mathrm{mM} \mathrm{MgCl}_{2} ; 1 \mathrm{mM}$ ATP; $0.25 \mathrm{mM}$ APP(NH)P; $10 \mathrm{mM}$ Tris- $\mathrm{HCl}(\mathrm{pH} \mathrm{7.4)}$. The opioid was incubated in this GTP buffer for $20 \mathrm{~min}$ at $37^{\circ} \mathrm{C}$. At the end of both incubations, the samples were centrifuged and the membrane pellets solubilized to immunoprecipitate the RGSZ2 and $\mu$-opioid receptors.

\section{Co-immunoprecipitation of Signaling Proteins}

Affinity-purified IgGs raised against the $\mu$-opioid receptors (Garzón et al, 1995, 2000), RGSZ1 (Garzón et al, 2004) and RGSZ2 (present work), were labeled with biotin (Sigma \#B1022). The $\mu$-opioid receptors, and the RGSZ1 and RGSZ2 proteins were immunoprecipitated from the solubilized synaptosomal fraction of mouse PAG using the protocol described previously with minor modifications (SánchezBlázquez et al, 2003). Briefly, about $1 \mathrm{~mm}$ of tissue around the aqueduct was taken from $2 \mathrm{~mm}$-thick coronal sections (MP-600 Micropunch, Activational Systems Inc.). This tissue was pooled from three to six mice and homogenized in 10 volumes of $25 \mathrm{mM}$ Tris- $\mathrm{HCl}(\mathrm{pH} 7.7), 1 \mathrm{mM}$ EGTA, and $0.32 \mathrm{M}$ sucrose supplemented with a protease inhibitor cocktail (Sigma, Madrid, Spain, \#P8340), a phosphatase inhibitor mix (Sigma, \#P2850), and H89 (Sigma, \#B1427). 
The homogenate was centrifuged at $1000 \mathrm{~g}$ for $10 \mathrm{~min}$ to remove the nuclear fraction (Sorvall RC5C, rotor SS-34, Newton, CT, USA) and the supernatant was centrifuged at $20000 \mathrm{~g}$ for $20 \mathrm{~min}$ to obtain the crude synaptosomal pellet $\mathrm{P} 2$. After two cycles of washing and resuspension in buffer followed by centrifugation, about $1 \mathrm{mg}$ of protein in the P2 pellet was solubilized by sonication at $4{ }^{\circ} \mathrm{C}$ (two cycles of $5 \mathrm{~s}$ each) in $400 \mu \mathrm{l}$ volume containing $50 \mathrm{mM}$ Tris- $\mathrm{HCl}$ ( $\mathrm{pH} 7.7)$, $50 \mathrm{mM} \mathrm{NaCl}, 1 \%$ Nonidet $\mathrm{P}-40$, protease and phosphatase inhibitor mixtures, H89. Solubilization was continued overnight at $4{ }^{\circ} \mathrm{C}$. The lysates were cleared with $20 \mu \mathrm{l}$ of streptavidin agarose (Sigma, \#S1638) pre-equilibrated for $1 \mathrm{~h}$ at $4^{\circ} \mathrm{C}$, and the protein content was determined with an assay suitable for Nonidet P-40-solubilized material (DC protein Assay, Biorad \#500-0116). About $0.8 \mathrm{mg}$ of the solubilized protein in $400 \mu \mathrm{l}$ was then incubated overnight at $4{ }^{\circ} \mathrm{C}$ with $3 \mu \mathrm{g}$ of affinity-purified biotinylated IgGs raised against $\mu$-opioid receptors, RGSZ2 or RGSZ1 proteins, and streptavidin agarose $(50 \mu \mathrm{l})$. The samples were centrifuged for $5 \mathrm{~min}$ at $3000 \mathrm{~g}$, and the agarose pellets recovered were subjected to three cycles of washing and resuspension in Nonidet P-40 buffer, followed by centrifugation. To detach and alter the tertiary structure of the proteins contained in the immune complexes, they were heated in $300 \mu \mathrm{l} 50 \mathrm{mM}$ Tris- $\mathrm{HCl}, 1 \% \mathrm{SDS}$ buffer for $10 \mathrm{~min}$ at $100^{\circ} \mathrm{C}$. The mixture was cooled to room temperature and the streptavidin agarose was separated in a centrifugal filter with a pore size of $0.45 \mu \mathrm{m}$ (Ultrafree-MC \#UFC30HV, Millipore Iberica, S.A.). Afterwards, a final concentration of $0.65 \%$ octyltioglucoside and fresh streptavidin agarose $(20 \mu \mathrm{l})$ was added to selectively remove the biotinylated IgGs that were detached during the initial heating. After $2 \mathrm{~h}$ at $4^{\circ} \mathrm{C}$, the samples were then centrifuged for $5 \mathrm{~min}$ at $10000 \mathrm{~g}$ and the streptavidin agarose containing the attached biotinylated IgGs was discarded. The proteins in the soluble fraction were concentrated in a centrifugal filter device (10000 nominal molecular weight limit, Amicon Microcon YM-10 \#42407, Millipore) and resolved by 10-16\% SDS-PAGE. An assay of these characteristics was enough for four to six gel lanes. The proteins were transferred to polyvinylidene difluoride membranes for Western blot analysis and incubated with the antibodies in DecaProbe chambers (PR 150, Hoefer-AmershamBiosciences, Barcelona, Spain). Pilot assays served to adjust the amount of IgGs, sample protein, and period of incubation to precipitate the desired proteins in a single run. Thus, a second run only provided remnant immunosignals. Equal loading was verified in reblotting assays and if necessary the signal adjusted using that obtained when probing the directly immunoprecipitated protein (mu receptor or RGSZ proteins). However, if signal interference was observed in the reblot assay, a parallel blot generated with the same immunoprecipitated samples was used to make the necessary adjustment.

\section{Animals and Evaluation of Antinociception}

Male albino mice CD-1 (Charles River), weighing 22-25 g, were housed and used strictly in accordance with the guidelines of the European Community for the Care and Use of Laboratory Animals (Council Directive 86/609/EEC). Animals were lightly anaesthetized with ether and all substances were injected into the lateral ventricles in $4 \mu \mathrm{l}$ volumes as previously described (Sánchez-Blázquez et al, 1995). The response of the animals to nociceptive stimuli was determined by the warm water $\left(52^{\circ} \mathrm{C}\right)$ tail-flick test. Baseline latencies ranged from 1.5 to $2.2 \mathrm{~s}$. Treatment with the selected active and mismatched ODNs did not alter the baseline latencies. Since the mismatched ODNs produced no changes in opioid activity when compared to salinetreated mice, the results obtained with these ODNs are presented as controls. Antinociception was expressed as a percentage of the maximum possible effect, $\mathrm{MPE}=100 \times$ (test latency-baseline latency)/(cutoff time(10s)-baseline latency). For the study, groups of 10-15 mice received a dose of the opioid agonists and antinociception was assessed at different time intervals thereafter. In these CD-1 mice, the supraspinal analgesic effects of $\delta$-opioid receptor agonists are moderate (see eg Garzón et al, 2003). The doses of $10 \mathrm{nmol}\left[\mathrm{D}-\mathrm{Pen}^{2,5}\right.$ ]-enkephalin (DPDPE) and $10 \mathrm{nmol}\left[\mathrm{D}-\mathrm{Ala}^{2}\right]$ deltorphin II produce comparable analgesic effects reaching about 50\% MPE. Statistical analysis of the results included analysis of variance (ANOVA) followed by the Student-Newman-Keuls test (SigmaStat, SPSS Science Software, Erkrath, Germany). The level of significance was set at $P<0.05$.

\section{Production and Evaluation of Acute Tolerance to Morphine}

Single i.c.v. injections of 3 or $10 \mathrm{nmol}$ morphine, or of 120 or 300 pmol DAMGO (priming doses) were used to study the production of acute tolerance and the effects compared with saline-administered controls. A second i.c.v. injection of either opioid (test dose) was given $24 \mathrm{~h}$ later when the pretreatment (priming dose) no longer affected baseline latencies. The analgesic effects were determined 15 min later for DAMGO or $30 \mathrm{~min}$ later for morphine. Acute tolerance was determined by a decrease in the antinociceptive potency. Every treatment was performed on a different group of 10 or 15 mice.

\section{Chemicals}

The opioids used were: morphine sulfate (Merck, Darmstadt, Germany), DAMGO (Tocris Cookson Ltd, Northpoint Fourth Way Avonmouth, UK, A1171), [D-Ala ${ }^{2}$ deltorphin II (Tocris, A1180), and DPDPE (Bachem, Bubendorf, Switzerland, H-2905).

\section{RESULTS}

\section{Glycosylation of RGSZ2 in the Mouse CNS}

We initially set out to determine the specificity of the antiserum that we had generated against RGSZ2. The affinity-purified IgGs directed against the C-terminal sequence of murine RGSZ2 recognized only the recombinant RGSZ2 and not the RGSZ1 protein (Figure 1a, lanes 3 and 2). The other RGS-Rz proteins, GAIP and RGSZ1, are heavily glycosylated in mouse brain synaptosomal membranes (Garzón et al, 2004), and computer-assisted analysis of the RGSZ2 sequence indicated that different glycosylated forms of this protein might exist (NetNGlyc 1.0 and NetOGlyc 2.0 Prediction Servers, Center for Biological 
Sequence Analysis). Indeed, in membranes isolated from PAG (Figure 1a, lane 4) and the cerebral cortex (Figure 1a, lanes 7 and 8), glycosylation of RGSZ2 did appear to occur since the antiserum recognized protein moieties of higher molecular weights that predicted for the RGSZ2 sequence.

The PAG is directly involved in the antinociceptive effects of opioids administered by the i.c.v. route (Yaksh et al, 1976). Thus, we wanted to evaluate the molecular changes that might underlie opioid receptor activation in this neural structure. However, the amount of synaptosomal proteins that can be obtained from PAG is seriously limiting when considering analyzing the glycosylated fractions. Therefore, to reduce the number of animals needed to a minimum, and since no differences in RGSZ2 expression were detected between these two neural structures (Figure 2), cerebral cortex tissue was used to obtain the glycosylated proteins instead of the PAG. When analyzing the WGL-purified glycosylated fraction, the band of about $24 \mathrm{kDa}$, present in the whole P2 fraction, was no longer detected (Figure 1a, lane 8). This size corresponds to the RGSZ2 protein according to the murine amino-acid sequence. In the glycosylated fraction, $\mathrm{N}$ - and $\mathrm{O}$-glycosidase activity greatly
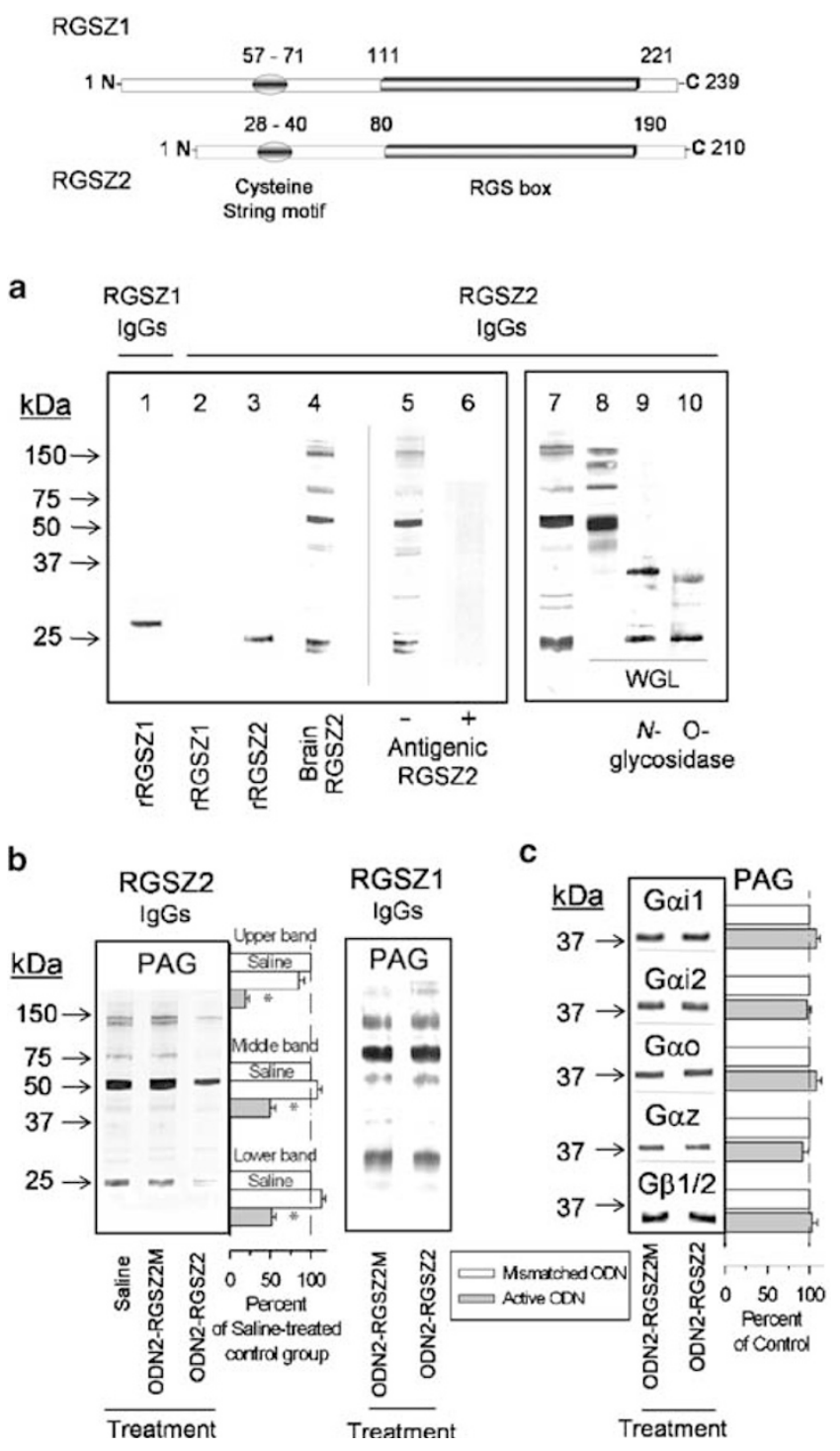

increased the electrophoretic mobility of the RGSZ2-like proteins, indicating that the higher molecular mass bands detected were glycosylated forms of RGSZ2 (Figure 1a, lanes 9 and 10). Notably, following glycosidase treatment of the WGL fraction, a $24 \mathrm{kDa}$ protein was recognized by the antiserum, this having the same size as the unmodified protein. Glycosylation of RGSZ2 is certainly complex and extensive, and probably occurs at multiple $N$ - and $O$-glycosylation sites, as is the case of RGSZ1 and GAIP (Garzón et al, 2004). To completely deglycosylate the RGS$\mathrm{Rz}$ proteins, it would be necessary to expose them to the several glycosidases with different sugar selectivity. However, modifications of the sugar trees by phosphorylation or the inclusion of sialic acid reduces the efficiency of glycosidases, and could account for the incomplete removal of the sugars.

In all neural areas evaluated, we detected both RGSZ2 mRNA and protein. RGSZ2 mRNA was most readily detected in the hypothalamus, PAG, and pons-medulla; lower levels were observed in the thalamus, followed by the cortex and spinal cord; and the weakest signals were seen in the striatum and cerebellum. The abundance of the protein expressed correlated well with the mRNA levels (Figure 2). Mammalian neural cells exhibit little RNase H activity, enabling antisense oligonucleotides to block the expression of target proteins in neural tissues through translational arrest rather than through the degradation of transcripts (see Sánchez-Blázquez et al (2003) and references therein). Thus, we assessed the efficacy and selectivity of the ODN treatments using antibodies against the RGSZ2 and RGSZ1 proteins. Both active antisense ODNs reduced the levels of the RGSZ2 protein to a similar degree but did not affect the

Figure I RGSZ2 protein in mouse brain: efficiency of ODN treatment. Characterization of the antibody generated against RGSZ2. (a) Western blot showing the proteins recognized by the antibody raised against RGSZ2. Lanes: I, 30 ng recombinant RGSZI protein probed with an antiRGSZI antibody (Garzón et al, 2004); 2, 3, and 4 correspond to 30 ng recombinant RGSZI protein, 30 ng recombinant RGSZ2, and $40 \mu \mathrm{g}$ mouse PAG synaptosomal fraction, respectively, probed with the anti-RGSZ2 antibody. Lanes 5 and 6, preincubation of the affinity-purified lgGs with $2 \mu \mathrm{g}$ of recombinant RGSZ2 for I $\mathrm{h}$ at room temperature abolished the binding of the antibody to the proteins identified in mouse PAG (the results are shown using lgGs incubated without $(-)$ and with $(+)$ the antigenic rRGSZ2, respectively). Glycosylated forms of RGSZ2. (a) Lanes: 7, $60 \mu \mathrm{g}$ of the P2 fraction from mouse cerebral cortex; 8, 9, and 10 correspond to wheatgerm lectin (WGL)-purified glycosylated proteins from the mouse cerebral cortex synaptosomal fraction. Lane 8 was loaded with $40 \mu \mathrm{g}$ of this material; in 9 and 10 the same material was subjected to the action of $\mathrm{N}$-glycosidase F and O-glycosidase, respectively. ODN-RGSZ2 treatment. (b) The effect of treatment with the active ODN over 5 days was assessed using saline, ODN2-RGSZ2 as the active ODN, and ODN2-RGSZ2M as the mismatched variant. Mice were killed on day 6 and the PAG structures from four mice were pooled. About $50 \mu \mathrm{g}$ of the SDS-solubilized synaptosomal fraction was resolved by SDS-PAGE (I 0-20\% acrylamide/ $2.6 \%$ bisacrylamide) and transferred to membranes. Immunodetection was carried out with affinity-purified IgGs directed against RGSZ2 and RGSZI. The immunoblots were analyzed as described in Methods section. (c) The ODN-induced knockdown of RGSZ2 had no effect on the expression of

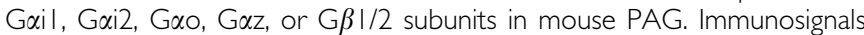
were analyzed by densitometry (Chemilmager IS-5500) and each bar is the mean \pm SEM of the percentage change with respect to the control of three to four independent determinations. *Significantly different from control protein levels from mice injected with the mismatched ODN, ANOVAStudent-Newman-Keuls test; $P<0.05$. 
levels of RGSZ1 immunoreactivity (Figure 1b). Nor did the knockdown of RGSZ2 protein alter the expression of the $\mathrm{G} \alpha \mathrm{z}, \mathrm{G} \alpha \mathrm{o}, \mathrm{G} \alpha \mathrm{i} 1 / 2$, or $\mathrm{G} \beta 1 / 2$ subunits that are involved in opioid signaling. For the sake of simplicity only the data corresponding to the activity of ODN2-RGSZ2 and the mismatched control sequence are shown here.

\section{RGSZ2 Regulates the Activity of Agonists at $\mu$-Opioid Receptors}

The time-course for the supraspinal antinociceptive activity of morphine is characterized by a slow rise that peaks about 20-30 min after the i.c.v. injection of the opioid (Figure 3).
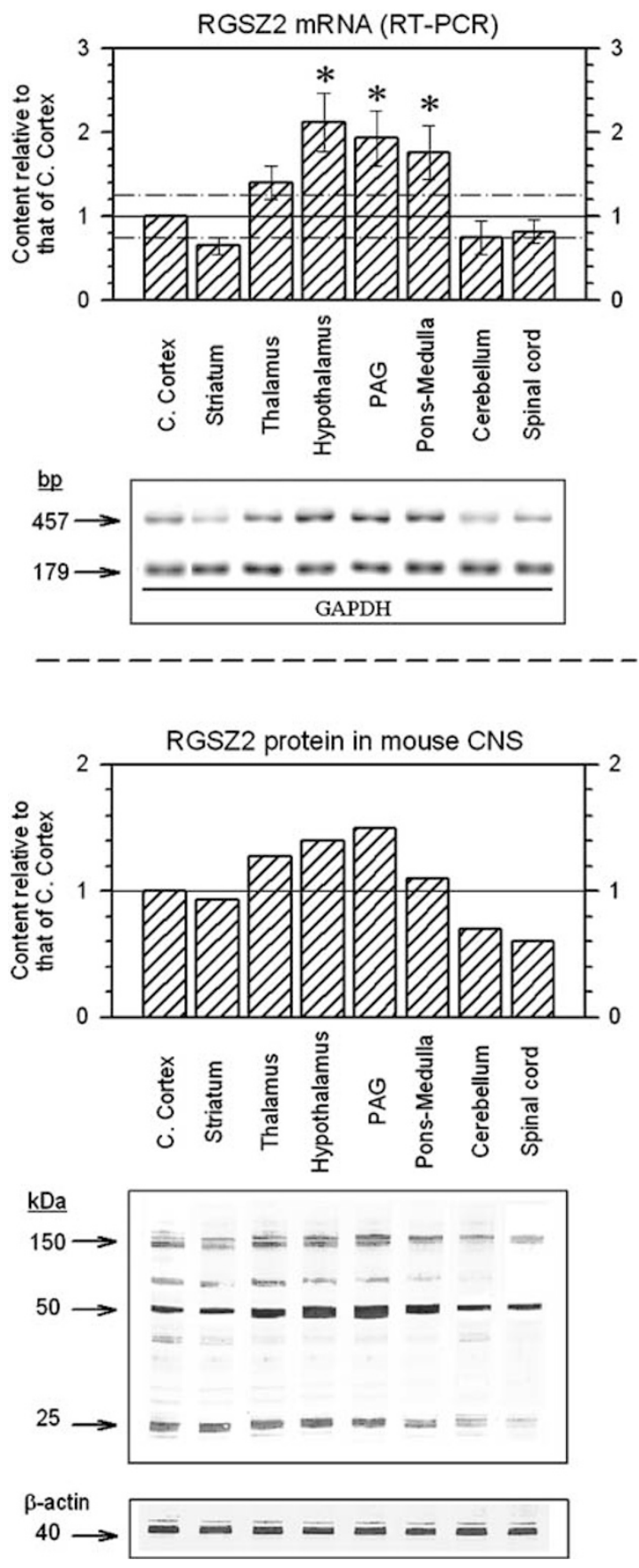

The ODN-induced knockdown of RGSZ2 significantly boosted and extended the antinociceptive activity of lower doses of morphine ( 1 and $3 \mathrm{nmol}$ ). This intensification was observed at various time points over the entire analgesic time-course with little change in the shape of the activation curves (Figure 3). However, at higher morphine doses (10 and $25 \mathrm{nmol}$ ), a smoother curve for the time-course was obtained when RGSZ2 expression was impaired. The effect of this opioid augmented nearly two-fold during the initial 5 and $10 \mathrm{~min}$ period post-morphine administration. Afterwards, the effect remained almost constant for a period of $60 \mathrm{~min}$ at $10 \mathrm{nmol}$ or for $120 \mathrm{~min}$ at $25 \mathrm{nmol}$, before remitting. During this plateau period, the effect of morphine was significantly lower than that produced in the mismatched ODN-RGSZ2-treated mice (Figure 3). The knockdown of the RGSZ1 protein also led to a notable enhancement in the capacity of morphine to promote antinociception, a two-fold increase was observed at several points in the time-course with both 1 and $10 \mathrm{nmol}$ morphine. The duration of the analgesia promoted by the higher dose of morphine was notably extended for an additional period of 60-90 min in these RGSZ1 knockdown mice (Figure 3; Garzón et al, 2004). These results suggest that the knockdown of the RGSZ2 proteins desensitizes certain effectors that are regulated by $\mu$ receptor-activated G $\alpha$ GTP subunits, leading to the rapid attenuation of agonist-evoked signals. The effects of high doses of morphine that remained in these animals were probably promoted by the activation of $\mathrm{G}$ proteins that exhibit a low capacity to promote $\mu$ receptor desensitization (eg of Gi2) on effectors that still show receptor regulation (Garzón et al, 2004; Sánchez-Blázquez et al, 2005). This was particularly relevant when higher doses of morphine were administered to mice with impaired RGSZ2 function. Lower doses of the opioid did not achieve the level of $\mu$ receptor-mediated G protein activation required to promote effector desensitization. The knockdown of the RGSZ1 protein led to an increase in the analgesic activity of morphine, similar to that observed for the lower doses of morphine in RGSZ2 knockdown mice. Thus, RGSZ1 probably exerts a less

Figure 2 RGSZ2 mRNA and protein in mouse brain. RT-PCR of RGSZ2 was performed on mRNA from different neural structures. A linear relationship was obtained for the amplification of the $457 \mathrm{bp}$ product from distinct amounts of RNA ranging from 0.05 to $0.25 \mu \mathrm{g}$. The densitometric signals associated with the amplification of RGSZ2 mRNA were normalized to those obtained by amplifying a 179 bp segment of GAPDH as an internal standard (AlphaEase v3.2.2 and using a Chemilmager IS-5500). Each bar is the mean \pm SEM of three separate experiments. *Significantly different from the mRNA levels observed for cerebral cortex (attributed an arbitrary value of I). ANOVA-Student-Newman-Keuls test (SigmaStat, SPSS Science Software); $P<0.05$. Presence of RGSZ2 immunoreactivity in different areas of mouse CNS. Mouse neural structures were collected and P2 fractions enriched in synaptosomes obtained. About $50 \mu \mathrm{g}$ of protein/ lane were resolved by SDS-PAGE and transferred to membranes. Immunodetection was carried out with IgGs against RGSZ2 as described in Methods section. Equal loading was verified and where necessary the signal adjusted using that obtained when probing the $\beta$-actin antibody. As signal interference was sometimes observed in reblotting assays, parallel blots were generated with the same samples to obtain the $\beta$-actin signals necessary for the adjustment. For every CNS structure analyzed, densitometric signals associated with 110,50, and $24 \mathrm{kDa}$ were pooled and those are shown in the figure. The experiment was conducted twice and similar results were obtained in both experiments. 

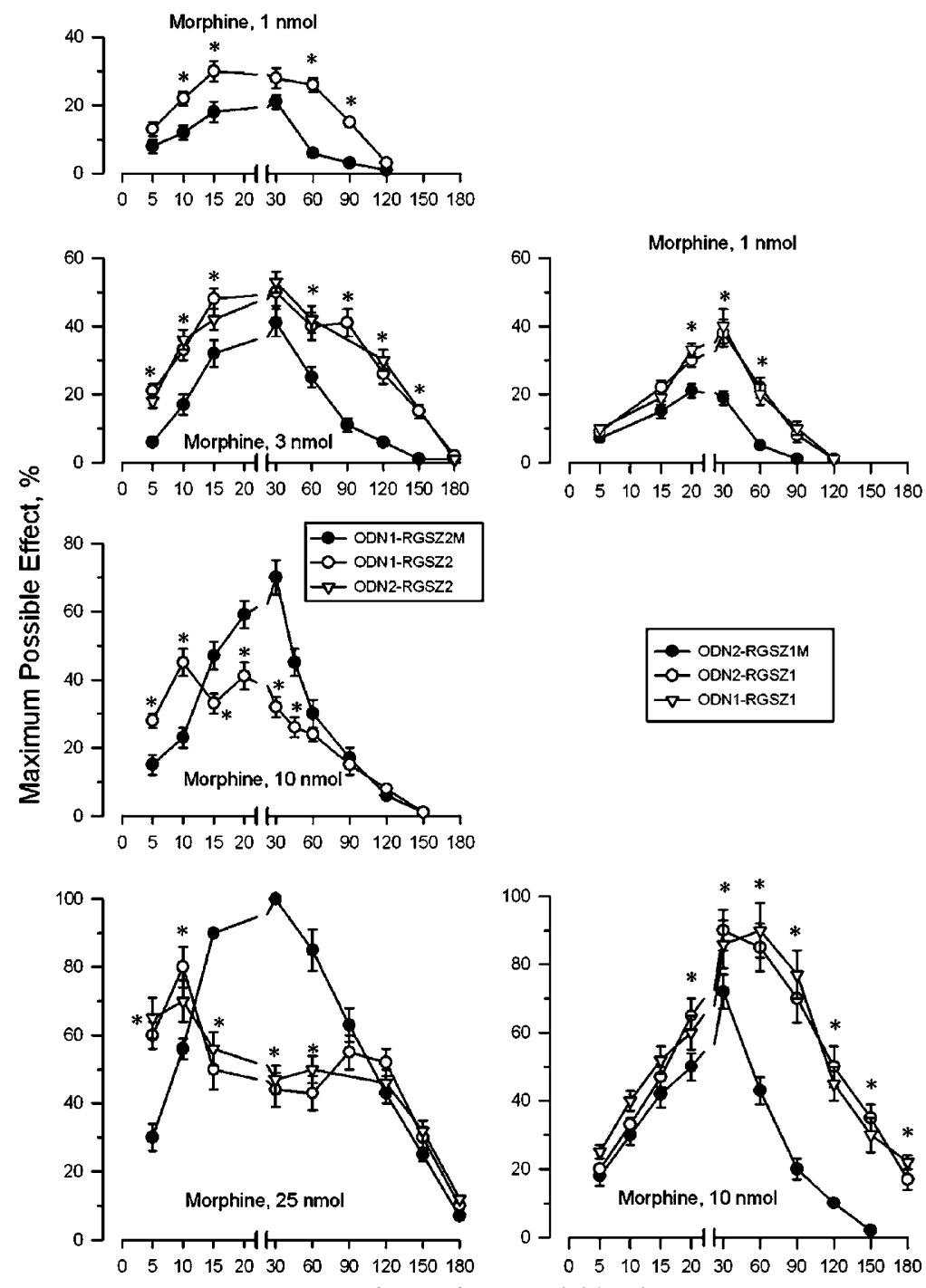

Interval post-opioid, min

Figure 3 Influence of RGSZ2 knockdown on the activity of morphine. Animals with reduced levels of RGSZ2 due to ODN treatment were administered morphine by i.c.v. injection on day 6 (after 5 days of ODN treatment). Antinociception was determined by the warm water ( $52^{\circ} \mathrm{C}$ ) tail-flick test at various time intervals postinjection. Values are mean \pm SEM from groups of 10-15 mice. *Significantly different from the group that had received the mismatched ODN. Since neither mismatched ODN produced changes in opioid activity, the results obtained with only one of these are presented as a control for the two active ODNs used.

intense influence than RGSZ2 on the regulation of G $\alpha$ GTP subunits with high desensitizing capacity.

In contrast to the knockdown of the RGSZ1 that produces a strong increase of DAMGO analgesic activity (Garzón et al, 2004), knockdown of the RGSZ2 protein brought about limited changes in the activity of DAMGO. While the efficiency of 120 pmol DAMGO increased in the intervals either side of the maximal effect (observed after $15 \mathrm{~min}$ ), at higher doses ( $300 \mathrm{pmol})$ the activity was boosted only in the period $5 \mathrm{~min}$ after DAMGO administration. Thus, it seems that when RGSZ2 production is impaired, $300 \mathrm{pmol}$ DAMGO provokes only a slight desensitization of the effectors acted upon by $\mu$ receptor-activated G $\alpha$ GTP. As a result, the activity of DAMGO is less intense than might be expected from the level of $G$ protein activation. The differences observed between morphine and DAMGO in promoting $\mu$ receptor desensitization could reside in the differential activation of $\mathrm{Gi} 2$ and $\mathrm{Gz}$ proteins in promoting analgesia (Garzón et al, 1997a,b), Gz being more active in this phenomena (Garzón et al, 2004; Sánchez-Blázquez et al, 2005). Furthermore, the knockdown of RGSZ2 promoted no changes on the analgesic activity of the $\delta$ receptor agonists [D-Pen ${ }^{2,5}$ ]-enkephalin (DPDPE) and [D-Ala $\left.{ }^{2}\right]$ deltorphin II (Figure 4).

\section{Increased $\mu$ Receptor-Mediated Acute Tolerance in RGSZ2 Knockdown Mice}

Impairment of RGSZ2 expression facilitated morphine and DAMGO desensitization of $\mu$ receptors in the acute 


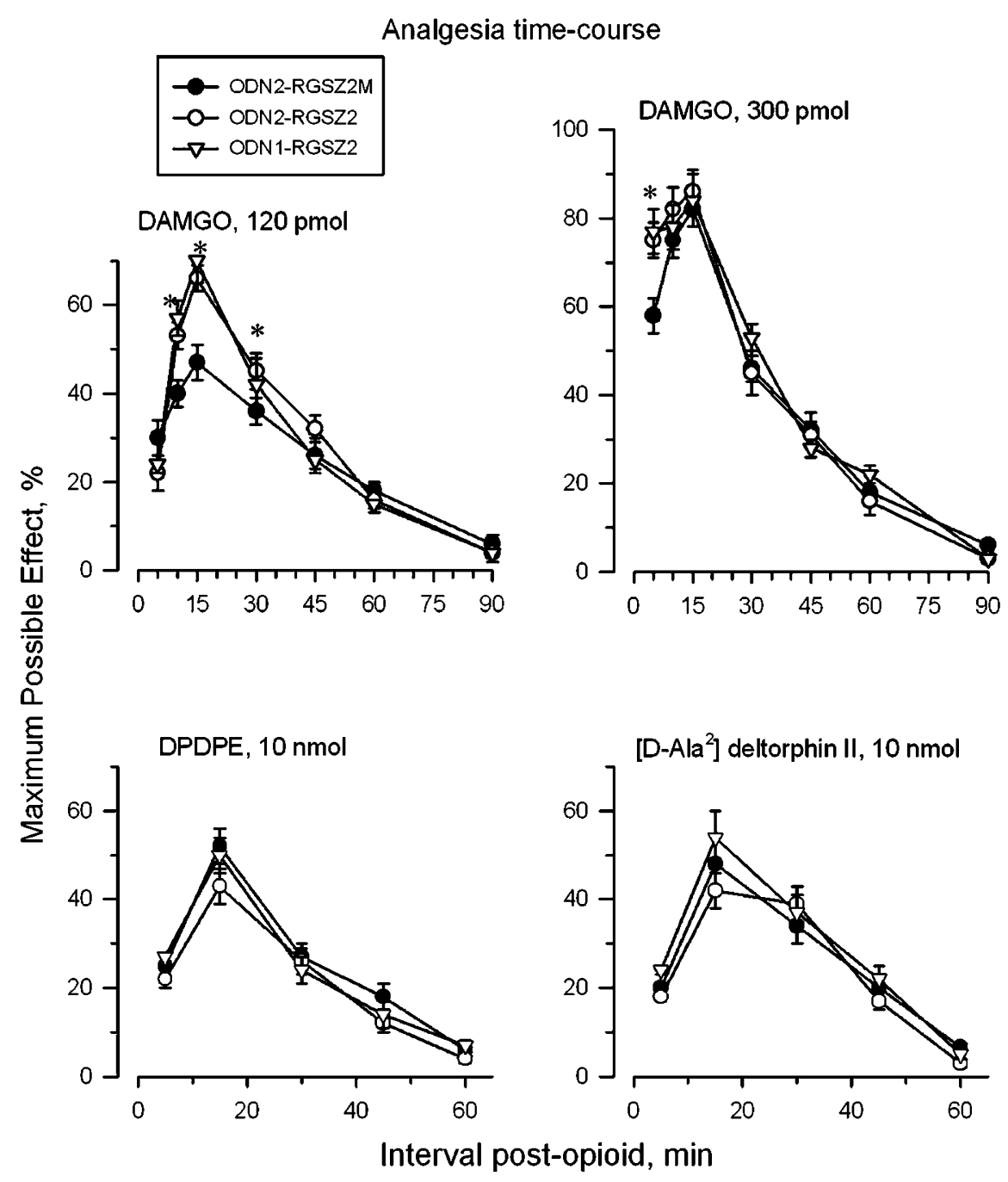

Figure 4 Knockdown of RGSZ2 and analgesia evoked by DAMGO and $\delta$-opioid agonists DPDPE and [D-Ala ${ }^{2}$ ] deltorphin II. Details as in the legend to Figure 3.

tolerance paradigm. In naïve mice, or in those treated with the control mismatched ODN1-RGSZ2M, administration of a priming dose of $3 \mathrm{nmol}$ morphine or of $120 \mathrm{pmol}$ DAMGO did not produce any tolerance to the effect of a second test dose $24 \mathrm{~h}$ later (Figure 5). Nevertheless, at higher doses of these $\mu$ opioids, $10 \mathrm{nmol}$ morphine or 300 pmol DAMGO, acute tolerance to the effects of a second dose were observed. In RGSZ2 knockdown mice, acute tolerance to the test doses was promoted even with the lower doses of morphine and DAMGO. In these mice, the analgesic activity of the priming dose of DAMGO $(120 \mathrm{pmol})$ increased after $15 \mathrm{~min}$ (Figure 4), whereas that of $10 \mathrm{nmol}$ morphine decreased at the 30 min time point studied (Figure 3). This diminished effect of morphine did not promote further desensitization to the effects of the $10 \mathrm{nmol}$ test dose (Figure 5a).

To test whether morphine and DAMGO act on the same $\mu$ receptors in the RGSZ2 knockdown mice, the agonists were injected to the mice sequentially. Morphine $(10 \mathrm{nmol})$ was administered first followed by DAMGO (120 pmol) $15 \mathrm{~min}$ later, and finally the overall effect was determined after a further $15 \mathrm{~min}$. In control mice, the analgesia evoked by the combination of both agonists was significantly higher than that of each agonist alone. In the RGSZ2 knockdown mice, $10 \mathrm{nmol}$ morphine showed a reduced effect $(30 \mathrm{~min}$ postopioid), while that of 120 pmol DAMGO increased after $15 \mathrm{~min}$ (see also Figure 3). In these mice, morphine antagonized DAMGO in its capacity to produce supraspinal analgesia (Figure 6a). In naive mice not exposed to the active ODNs, adequate doses of morphine and DAMGO did produce acute crosstolerance (Figure $6 \mathrm{~b}$ ). Therefore, both agonists appear to exert their effects through the $\mu$-opioid receptors and trigger similar signaling mechanisms. These results confirm that when RGSZ2 is knocked down, morphine provokes the rapid desensitization of $\mu$ signaling and reduced DAMGO activity when it reached the receptor. Thus, the impairment of RGSZ2 function augmented the capacity of these agonists to desensitize $\mu$ receptors, particularly morphine which was now able to promote desensitization within its analgesic time-course (see Figure 2).

\section{The Preference of Agonists in Activating Gz and Gi2 Proteins Via $\mu$ Receptors}

In synaptosomal preparations of mouse PAG, antibodies against $\mu$-opioid receptors precipitated glycosylated pro- 
1640

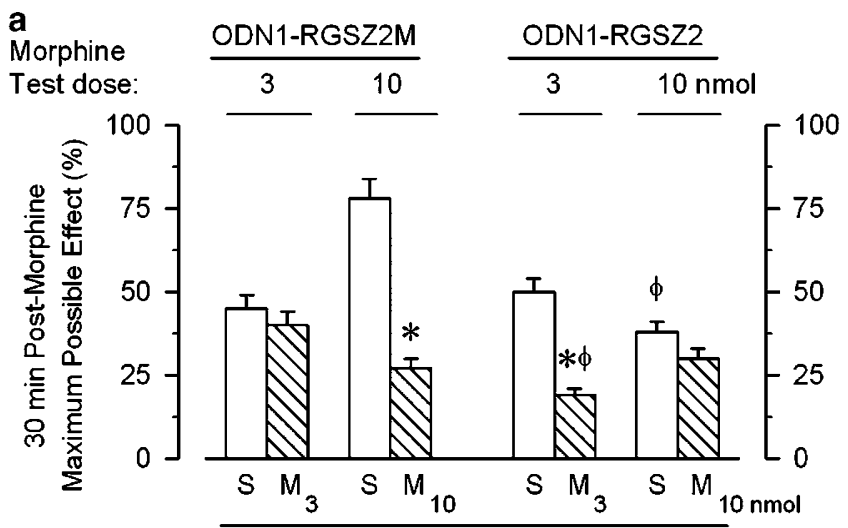

Saline (S) or Morphine (M) Priming dose

( $24 \mathrm{~h}$ before test dose)

b

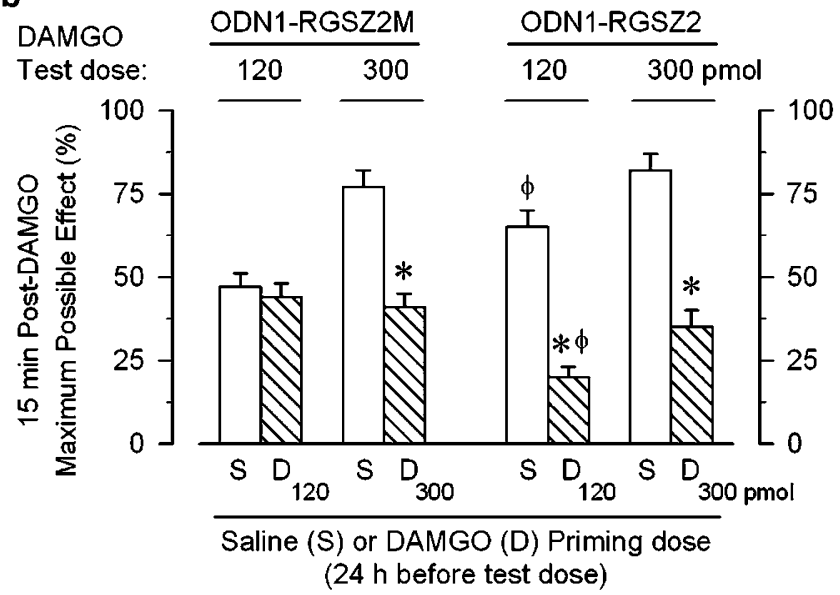

Figure 5 Role of RGSZ2 proteins on acute tolerance to single doses of morphine and DAMGO. (a) Either saline or priming doses of morphine (3 and $10 \mathrm{nmol}$ ) were injected i.c.v. into mice that had received the active ODNI-RGSZ2 or the control mismatched ODN. After $24 \mathrm{~h}$, all groups received an i.c.v. test injection of 3 or $10 \mathrm{nmol}$ morphine and the analgesic effects were evaluated 30 min later. Values are mean \pm SEM from groups of 10-15 mice. *Significantly different from the corresponding group injected with saline before the second dose of the opioid, $\Phi$ from the group treated with the mismatched ODN and injected with saline before the second dose of the opioid. ANOVA-Student-Newman-Keuls test; $P<0.05$. (b) DAMGO priming and test doses of 120 and 300 pmol were used. Antinociception was evaluated $15 \mathrm{~min}$ after the DAMGO test dose challenge. Details as in (a).

teins of $55-65,70-80$, and $100-110 \mathrm{kDa}$. Antibodies directed against two epitopes on the $\mu$ receptor confirmed that these bands corresponded to the sought after proteins. In contrast, no $\mu$ receptor was immunoprecipitated from 57BL/6 $\mu$-opioid receptor null $(-/-)$ mice (Figure $7 \mathrm{~b}$ ). The activity of $\mathrm{N}$-glycosidase $\mathrm{F}$ augmented the electrophoretic mobility of the bands to the size predicted from the $\mu$ receptor amino-acid sequence (Garzón et al, 1995). Activation of the $\mathrm{Gz}$ and $\mathrm{Gi} 2$ proteins by morphine and DAMGO via $\mu$ receptors was examined in in vitro and ex vivo assays. PAG synaptosomal membranes were incubated with the $\mu$ agonists and GTP $\gamma$, a nucleotide that is resistant to $\mathrm{G} \alpha \mathrm{GTP}$ ase and that exhibits a very low dissociation rate. These properties help to maintaining the agonist-activated $\mathrm{G} \alpha \mathrm{GTP} \gamma \mathrm{S}$ subunits separated from the receptors. When a
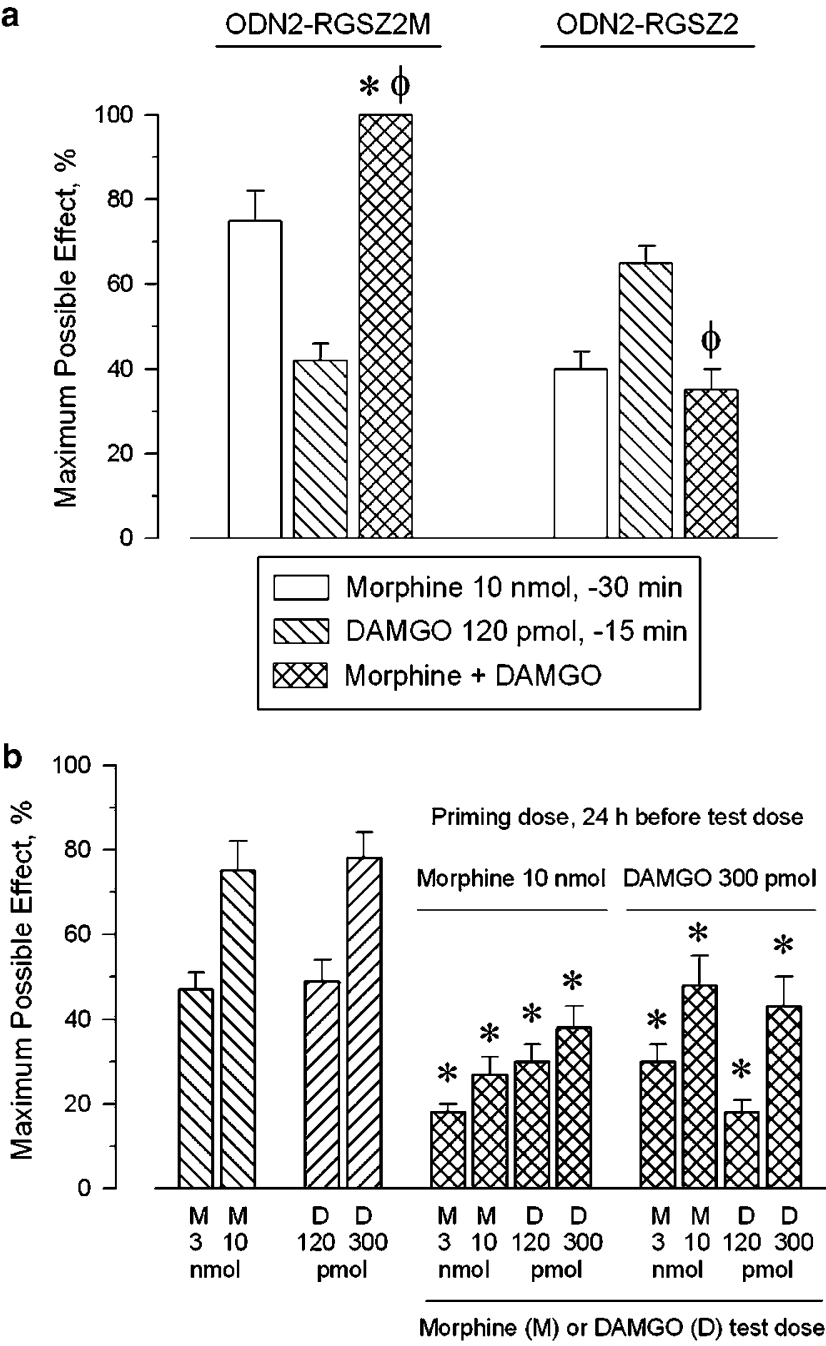

Figure 6 Crosstolerance between morphine and DAMGO to produce antinociception. (a) Agonist-antagonist activities of morphine in mice after impairment of RGSZ2 function. The active ODN2-RGSZ2 was administered as described in Methods section. Control groups received the mismatched ODN2-RGSZ2M. While the impairment of RGSZ2 reduced the activity of $10 \mathrm{nmol}$ morphine, it increased the effect of $120 \mathrm{pmol}$ DAMGO; both measured at the intervals of the maximal effect (30 min for morphine and $15 \mathrm{~min}$ for DAMGO). To analyze the interaction between morphine and DAMGO, the alkaloid was injected 15 min before DAMGO. The antinociceptive activity was evaluated 15 min later in the warm water test for analgesia. Each experimental group consisted of 10-15 mice. *Effect of the combined agonists that was significantly different with respect to that of $10 \mathrm{nmol}$ morphine acting alone, $\Phi_{v s}$ the effect promoted by $120 \mathrm{pmol}$ DAMGO alone. ANOVA-Student-Newman-Keuls test; $P<0.05$. (b) Two groups of mice received a priming dose of $10 \mathrm{nmol}$ morphine or $300 \mathrm{pmol}$ DAMGO. After $24 \mathrm{~h}$, each group was subdivided into four groups to study i.c.v. test doses of 3 and $10 \mathrm{nmol}$ morphine, and of 120 and $300 \mathrm{pmol}$ DAMGO. Analgesia was evaluated $30 \mathrm{~min}$ after morphine and 15 min after DAMGO administration. The bars on the left indicate the effects promoted by these doses of the opioids in mice that had received saline instead of the priming doses of these opioids. Each experimental group consisted of 8-12 mice. *Significantly different from the corresponding group injected with saline before the second dose of the opioid, ANOVA-Student-Newman-Keuls test; $P<0.05$.

challenged with either morphine or DAMGO, the amount of $\mathrm{G} \alpha \mathrm{z}, \mathrm{G} \alpha \mathrm{i} 2$, and $\mathrm{G} \alpha \mathrm{o}$ proteins that co-precipitated with $\mu$ receptors was reduced. While morphine produced a more 

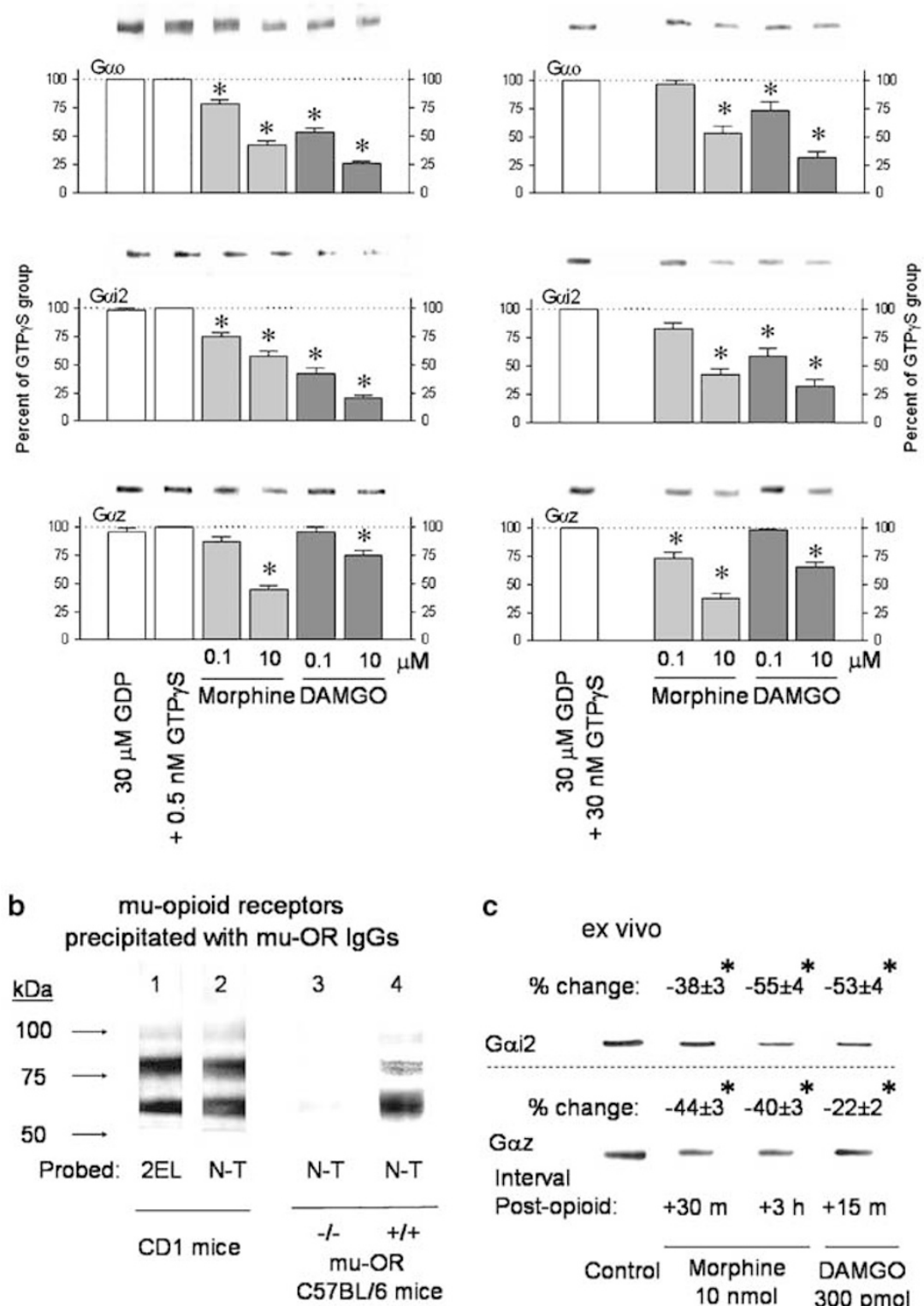

C

ex vivo

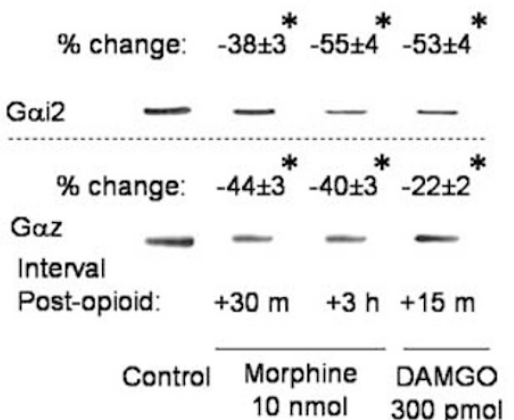

Figure 7 Co-precipitation of $\mathrm{G} \alpha$ subunits with $\mu$-opioid receptors. (a) Mouse PAG membranes enriched in synaptosomes were incubated at $25^{\circ} \mathrm{C}$ for I $\mathrm{h}$

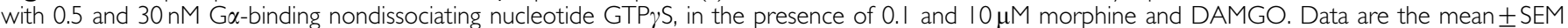
from three or four determinations. (b) After Nonidet P-40 solubilization of the synaptosomal membranes of CDI and C57BL/6 mice, the $\mu$-opioid receptors were precipitated with: lane I, biotinylated IgGs directed to the $\mathrm{N}$ terminal (N-T) of $\mu$-opioid receptors; lanes 2, 3, and 4, biotinylated lgGs directed to the 2nd external loop (2EL) of $\mu$ receptors. After removing the lgGs, the blots were probed with antibodies directed against: lane I, 2EL; lanes 2, 3, and 4, the $\mathrm{N}-\mathrm{T}$ epitope. (c) Groups of three mice i.c.v. injected with $10 \mathrm{nmol}$ morphine or 100 pmol DAMGO were killed at the interval post-opioid administration indicated. The PAG synaptosomal membranes were obtained at each interval and the experiment was repeated three times on different groups of mice. Densitometry data are expressed as mean \pm SEM. For (a) and (c), the PAG membranes were solubilized with $1 \%$ Nonidet P-40 and incubated overnight at $4^{\circ} \mathrm{C}$ with affinity-purified biotinylated IgGs raised against the 2 nd external loop of the $\mu$-opioid receptor. Immunocomplexes were precipitated with

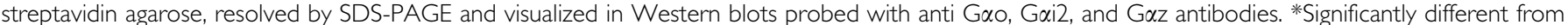
the data from control group that received saline instead of the opioid, ANOVA-Student-Newman-Keuls test; $P<0.05$.

potent reduction of $\mu$ receptor-associated $\mathrm{G} \alpha \mathrm{z}$ subunits than DAMGO, the opposite occurred when the segregation of $\mathrm{G} \alpha \mathrm{i} 2$ and $\mathrm{G} \alpha \mathrm{o}$ proteins from the $\mu$ receptors was analyzed (Figure 7a). These effects of both opioid agonists on the association of $\mathrm{G} \alpha$ subunits to $\mu$ receptors were antagonized above $50 \%$ by $10 \mu \mathrm{M}$ naloxone (not shown). Morphine or DAMGO promoted reductions in the association of $\mathrm{G} \alpha$ subunits with $\mu$ receptors in PAG membranes of mice injected i.c.v. with these agonists and killed at intervals corresponding to the maximal analgesic effects and beyond. When used at equivalent effective doses, $70-80 \%$ MPE in the analgesic test, both agonists reduced the $\mathrm{G} \alpha \mathrm{i} 2$ proteins that co-precipitated with the $\mu$ receptors by $40-50 \%$. However, morphine provoked a $40 \%$ reduction in the $\mathrm{G} \alpha \mathrm{z}$ linked to this opioid receptor, compared to a $20 \%$ reduction with DAMGO (Figure 7c). 
a

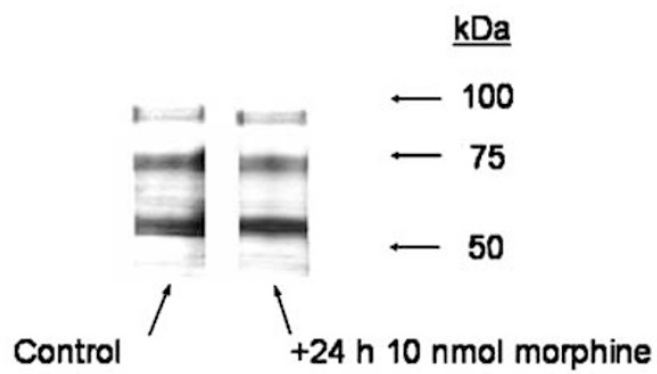

Mu-opioid receptors precipitated with anti mu receptor IgGs

b Ga subunits co-precipitated with mu-opioid receptors C: Control saline, $-24 \mathrm{~h}$

$\mathrm{T}$ : $10 \mathrm{nmol}$ morphine, $-24 \mathrm{~h}$

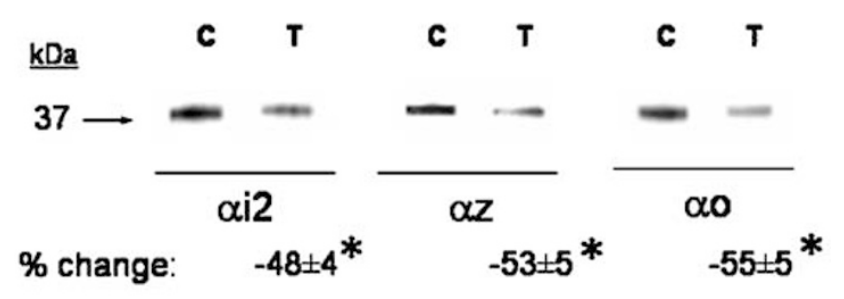

\section{C: Control saline, $-24 \mathrm{~h}$}

T: $3 \mathrm{nmol}$ morphine, $-24 \mathrm{~h}$

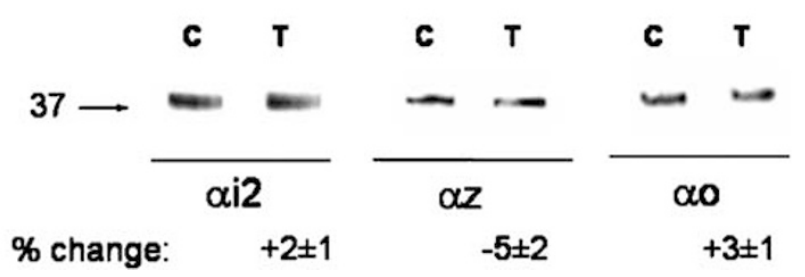

Figure 8 Co-precipitation of $\mathrm{G} \alpha$ subunits with $\mu$-opioid receptors. Groups of 6-10 mice received a single i.c.v. injection of saline (control), 3 or $10 \mathrm{nmol}$ morphine, and were killed $24 \mathrm{~h}$ later. The pooled PAG synaptosomal membranes were solubilized with 1\% Nonidet P-40 and incubated overnight at $4^{\circ} \mathrm{C}$ with affinity-purified biotinylated IgGs raised against the 2 nd external loop of the $\mu$-opioid receptor. Immunocomplexes were precipitated with streptavidin agarose, resolved by SDS-PAGE and visualized in Western blots probed with: (a) an antibody directed to an epitope in the $\mathrm{N}$-terminal sequence of the $\mu$-opioid receptor; (b) antibodies directed to peptide sequences in $\mathrm{G} \alpha 0, \mathrm{G} \alpha \mathbf{2}$, and $\mathrm{G} \alpha z$ subunits. * Significantly different from the data from control group that received saline instead of the opioid, ANOVA-Student-Newman-Keuls test; $P<0.05$.

\section{Co-precipitation of G $\alpha \mathrm{i} / \mathrm{o} / \mathrm{z}$ Subunits with $\mu$-Opioid Receptors and with RGSZ1 and RGSZ2 Proteins}

The administration of a desensitizing dose of $10 \mathrm{nmol}$ morphine promoted no noticeable changes in the pattern of the $\mu$ receptors precipitated from PAG membranes of mice killed $24 \mathrm{~h}$ later (Figure 8a). However, morphine induced a long-term decrease in the extent to which G-proteins associated with the $\mu$ receptors in a dose-dependent manner. This phenomenon could be seen $24 \mathrm{~h}$ after $10 \mathrm{nmol}$ morphine was administered, a dose capable of producing acute tolerance. However, a lower dose of $3 \mathrm{nmol}$ neither produced acute tolerance nor promoted a significant change in the association of $\mathrm{G} \alpha \mathrm{i} 2 / \mathrm{o} / \mathrm{z}$ with $\mu$ receptors over this interval (Figure $8 \mathrm{~b}$ ). While a substantial amount of the $\alpha$ subunits of $\mathrm{Gi} 2$, Go, and $\mathrm{Gz}$ proteins were co-precipitated with RGSZ2 in pull-down assays, little of the G $\alpha z$ subunits co-precipitated with RGSZ1 IgGs (Figure 9a). This assay was also performed on PAG membranes from mice that had received a dose of $10 \mathrm{nmol}$ morphine, capable of promoting acute tolerance, $24 \mathrm{~h}$ prior to their killing. In these circumstances, the amount of G $\alpha \mathrm{i} 2$ that co-precipitated with RGSZ1 and RGSZ2 increased by $30-40 \%$, while the amount of $\mathrm{G} \alpha \mathrm{o}$ increased by 20 and $30 \%$, respectively (Figure 9a upper panel). Interestingly, the $\mathrm{G} \alpha \mathrm{z}$ retained by RGSZ2 increased by $70 \%$ both $30 \mathrm{~min}$ and $3 \mathrm{~h}$ after $10 \mathrm{nmol}$ morphine was administered, and the increase in $\mathrm{G} \alpha \mathrm{z}$ remained $30 \%$ higher after $24 \mathrm{~h}$. A lower dose of $3 \mathrm{nmol}$ morphine promoted more limited increases in the association of G $\alpha \mathrm{z}$ with RGSZ2 proteins that reverted to control levels within $24 \mathrm{~h}$. Moreover, after administering $10 \mathrm{nmol}$ morphine, G $\alpha$ z was hardly seen to associate with RGSZ1 proteins. Notably, the action of morphine greatly increased the association of G $\alpha \mathrm{i} 2$ subunits with RGSZ2 proteins and to a lesser extent with RGSZ1 proteins. These increases were observed after $30 \mathrm{~min}$ and $3 \mathrm{~h}$ of $3 \mathrm{nmol}$ morphine administration and were still present $24 \mathrm{~h}$ after delivery of $10 \mathrm{nmol}$ morphine (Figure 9a upper and lower panels). The action of $10 \mathrm{nmol}$ morphine did not alter the presence of RGSZ2 or RGSZ1 proteins in PAG membranes (Figure $9 b$ and c).

In in vitro assays carried out on PAG membranes, $3 \mu \mathrm{M}$ morphine promoted the segregation of $\mathrm{G} \alpha \mathrm{i} 2$ subunits from the $\mu$-opioid receptors in the presence of GTP as well as in the presence of its nonhydrolyzable analog GTP $\gamma \mathrm{S}$ (Figure 10). However, the opioid induced Gai2 subunits to tightly associate with RGSZ2 proteins only when GTP was used as the activator of $G$ proteins, this association being observed in the immunoprecipitated material. The inability to detect the association of $\mathrm{G} \alpha \mathrm{GTP} \gamma \mathrm{S}$ with RGSZ2 proteins indicates that the solubilization that precedes the immunoprecipitation procedure disrupts this interaction. Thus, it appears that a nucleotide form other than GTP stabilizes the binding of G $\alpha$ GTP to RGSZ proteins, and this is likely to be GDP.

\section{Co-precipitation of RGSZ1 and RGSZ2 Proteins with $\mu$-Opioid Receptors}

In solubilized PAG synaptosomal membranes, pull-down of $\mu$-opioid receptors co-precipitated both RGSZ2 and RGSZ1 proteins (Figure 9d). This procedure enriched the intensity of some of the RGSZ1 and RGSZ2 bands found in PAG membranes (Figures 1a and 2; Garzón et al, 2004).

\section{DISCUSSION}

The RGSZ2 protein, a member of the RGS-Rz subfamily, regulates $\mathrm{Gi} / \mathrm{o} / \mathrm{z}$-protein signaling in vitro (Mao et al, 2004) and can be found in specific areas of the mouse CNS. The highest levels of RGSZ2 mRNA and protein were found in the hypothalamus, PAG-midbrain, and pons-medulla. The 
a

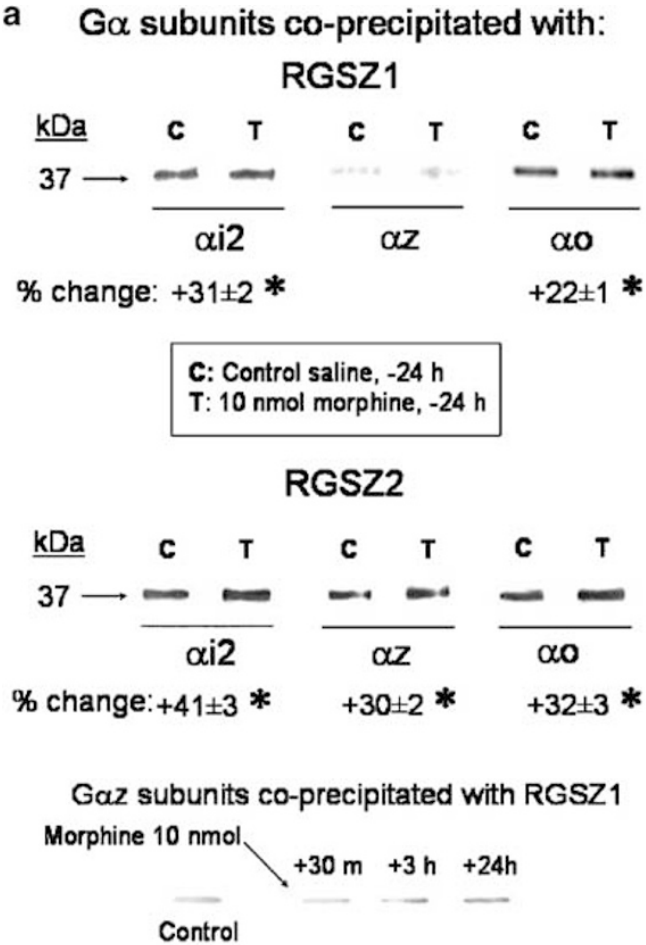

Gaz subunits co-precipitated with RGSZ2

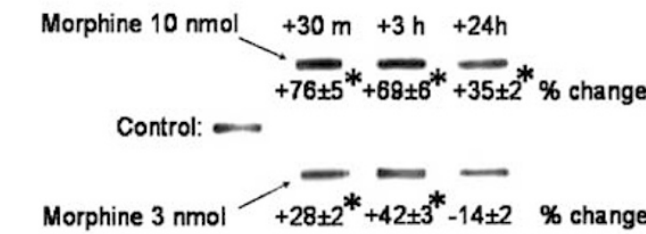

Gai2 subunits co-precipitated with:

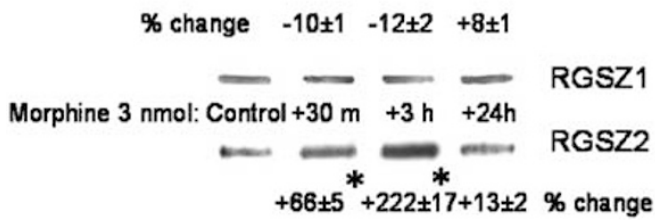

b

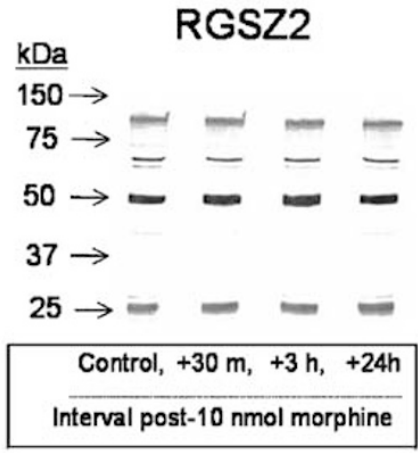

c

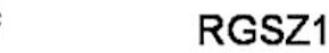

d

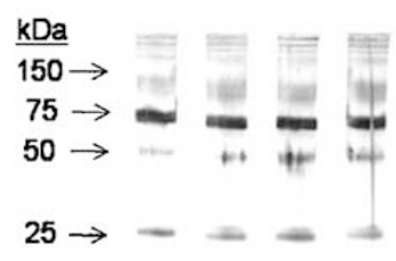

d

RGS-Rz co-precipitated with mu-OR IgGs

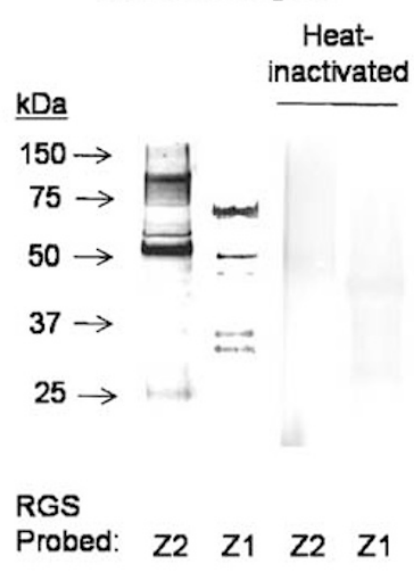

Figure 9 Co-precipitation of RGSZ2 and RGSZI with $\mu$-opioid receptors. The association of G $\alpha$ subunits with RGSZ2 and RGSZI proteins is modulated by morphine. (a) 3 and $10 \mathrm{nmol}$ morphine were i.c.v. injected into mice at various intervals before they were killed. PAG membranes were obtained, solubilized and RGSZ2 and RGSZI proteins were immunoprecipitated with specific antibodies. In Western blots, the presence of the G $\alpha 0$, G $\alpha i 2$, and G $\alpha z$ subunits was analyzed. Equal loading was verified and if necessary the signal was adjusted using that obtained when probing the RGSZI or RGSZ2 antibodies. This was conducted in parallel blots generated with the same samples used to study the co-precipitation of $\mathrm{G} \alpha$ subunits in control and morphine-treated mice. (b, c) Representative blots probed with RGSZ2 and RGSZI antibodies are shown. These were from immunoprecipitation studies conducted with biotynated affinity-purified IgGs directed against RGSZ2 or RGSZI proteins on NP-40-solubilized PAG membranes of control and I0 nmol morphine i.c.v.injected mice. (d) Solubilization of PAG membranes and immunoprecipitation of $\mu$-opioid receptors was performed as described in Methods section and in Figure 7. The precipitate was resolved by SDS-PAGE and Western blots were proved with affinity-purified lgGs against the RGSZ2 and RGSZI proteins. *Significantly different from the data from control group that received saline instead of the opioid, ANOVA-Student-Newman-Keuls test; $P<0.05$.

structurally related RGSZ1 protein shows a more uniform expression, whereas GAIP accumulates in the striatum, thalamus, and hypothalamus (Garzón et al, 2004). The RGS$\mathrm{Rz}$ proteins contain several potential $\mathrm{N}$ - and $\mathrm{O}$-linked glycosylation sites, as well as consensus sites for serine, threonine, and tyrosine phosphorylation (De Vries et al, 1995; Center for Biological Sequence Analysis). RGSZ2related protein moieties of distinct sizes were detected in immunoblots of synaptosomal membranes, as is the case for RGSZ1 and GAIP (Carrasco et al, 2004; Garzón et al, 2004). With the exception of the $24 \mathrm{kDa}$ moiety, these RGSZ2 forms were purified in the glycosylated pool of neural membrane proteins and following treatment with glycosidases, their apparent molecular weight decreased. Since analysis of the RGSZ2 gene revealed a low probability of splicing (Mao et al, 2004), these RGSZ2 moieties seems to be 
Goi2 co-precipitated with mu receptors

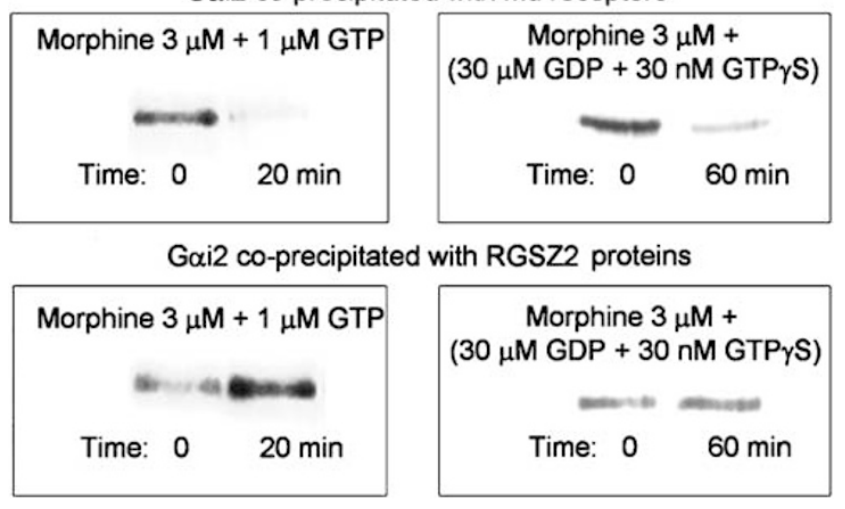

Figure 10 Morphine affects the association of Goi2 subunits with RGSZ2 proteins and $\mu$-opioid receptors in vitro. Mouse PAG membranes enriched in synaptosomes were incubated in the presence of $3 \mu \mathrm{M}$ morphine for $\mathrm{I}$ h at $25^{\circ} \mathrm{C}$ with $30 \mathrm{nM} \mathrm{GTP \gamma S}$, or for $20 \mathrm{~min}$ at $37^{\circ} \mathrm{C}$ with I $\mu$ M GTP. After centrifugation, the resulting pellet was solubilized and the $\mu$-opioid receptors and RGSZ2 proteins immunoprecipitated (see Methods and Figure 7). The precipitate was resolved by SDS-PAGE, the proteins immobilized, and Western blots were proved with antibodies directed against the Gai2 subunits. The experiment was repeated twice and the results were similar on both occasions.

the result of glycosylation and phosphorylation at diverse sites.

The impairment of RGSZ2 function produced a notable increase in the potency and duration of supraspinal analgesia elicited by the lower doses of morphine studied. However, the effects of the higher doses of the opioid were enhanced at the early time points only, and subsequently $\mu$ receptor signaling desensitized. In these RGSZ2 knockdown mice, the activity of the lower dose of DAMGO also appeared to increase at intervals close to those in which the maximal effect was observed. The higher dose of this opioid probably promoted some degree of desensitization as its potency only augmented at the initial $5 \mathrm{~min}$ time point. Notably, impairment of RGSZ1 function enhanced the potency and duration of morphine and DAMGO at all the doses studied (Garzón et al, 2004; present work).

In the RGSZ2 and RGSZ1 knockdown mice, acute tolerance developed in response to doses of morphine and DAMGO that failed to produce this effect in control mice. These observations suggest that the enhancement of $\mu$ agonist signaling produced in RGSZ2 or RGSZ1 knockdown mice intensified the desensitization of $\mu$-opioid receptors. This phenomenon diminishes after reducing the levels of G $\alpha$ z, but not G $\propto \mathrm{i} 2$ subunits (Garzón et al, 2004; SánchezBlázquez et al, 2005). Thus, $\mathrm{Gz}$ proteins appear to play an important role in morphine-induced acute tolerance. In the propagation of their effects, the agonists show preference towards particular receptor-regulated G-proteins, as is the case for $\mu$-, $\delta$ - and $\kappa$-opioid receptors (Kohno et al, 2000; Sánchez-Blázquez et al, 1999, 2001). In PAG membranes, morphine is more efficient than DAMGO in activating Gz proteins (Garzón et al, 1997a, b). Indeed, immunoprecipitation of $\mu$ receptors with associated G-proteins confirmed that morphine and DAMGO display distinct preferences in terms of activating Gz or Gi2 proteins. Therefore, in RGSZ2 and RGSZ1 knockdown mice, the greater capacity of morphine to act on $\mathrm{Gz}$ proteins led to a fast and pronounced desensitization of $\mu$ receptor signaling. It is possible that in these mice, the effects that remained after administering doses of $10 \mathrm{nmol}$ morphine and above are produced by the activity of G $\alpha \mathrm{i} / \mathrm{o}$ subunits on effectors other than those acted upon by the G $\alpha$ z subunits. Indeed, there are some reports detailing the preferences of different classes of $G$ proteins in the regulation of certain effectors, for example, $\mathrm{G} \alpha \mathrm{o}$ and adenylyl cyclase $\mathrm{V}$ (Zaworski et al, 1999), G $\alpha$ z, and adenylyl cyclases II and VI (Ho et al, 2000).

The unique biochemical and regulatory properties of $\mathrm{G} \alpha \mathrm{z}$ subunits could account for their elevated desensitizing capacity. The pertussis toxin-insensitive $\mathrm{Gz}$ transducer protein and $\mathrm{Gi} / \mathrm{o}$ proteins regulate the activity of adenylyl cyclases (Wong et al, 1992) and the gating of certain $\mathrm{K}^{+}$ channels (Jeong and Ikeda, 1998). However, G $\alpha \mathrm{z}$ is predominantly confined to neuronal cells (Fong et al, 1988; Hinton et al, 1990) and is subjected to a variety of covalent modifications that modulate its signaling properties including phosphorylation (Lounsbury et al, 1991), myristoylation (Mumby et al, 1990), arachidonoylation, and palmitoylation (Hallak et al, 1994). The rate of GDP dissociation intrinsic to $G \alpha z$ is quite low and the rate of nucleotide exchange is reduced to nearly zero at $\mathrm{Mg}^{2+}$ concentrations above those found physiologically (Casey et al, 1990). This effect of $\mathrm{Mg}^{2+}$ is specific to $\mathrm{G} \alpha \mathrm{z}$ subunits and is qualitatively similar to that observed for the monomeric G proteins such as Ras (Hall and Self, 1986). Moreover, the rate of G $\alpha$ GGTP hydrolysis is as much as 200fold slower than that of G $\alpha$ sGTP and GaiGTP (Casey et al, 1990). This indicates that $\mathrm{Gz}$ may be difficult to switch off after receptor activation unless there are external factors that accelerate the rate of GazGTP hydrolysis in the same way that the GAPs do for many Ras-like proteins. Therefore, inadequate control of $\mathrm{G} \alpha \mathrm{z}$ signaling could easily lead to excessive activity on the target effectors and subsequent desensitization.

Agonist desensitization can also be promoted at the Gprotein level. In fact, a single dose of $10 \mathrm{nmol}$ morphine brought about a long-term reduction in the amount of $\mathrm{G} \alpha \mathrm{i} /$ $\mathrm{o} / \mathrm{z}$ subunits that co-precipitated with $\mu$ receptors. Therefore, a fraction of the activated $G \alpha$ subunits is not longer regulated by the receptor after the effects of the agonist have disappeared. After $24 \mathrm{~h}$, a second administration of the same dose of the opioid produced a much lower effect, revealing the existence of acute tolerance. As well as these effects, morphine also promoted the association of $\mathrm{G} \alpha$ subunits with RGSZ proteins. While the Gai/o subunits coprecipitated with both RGSZ1 and RGSZ2 proteins, G $\alpha$ Z only stably associated with RGSZ2 proteins. At its maximal effect $30 \mathrm{~min}$ after the morphine challenge, there was a large increase in the association of $\mathrm{G} \alpha \mathrm{z}$ subunits with RGSZ2 proteins. Their relationship persisted for $3 \mathrm{~h}$ after the analgesic effects ceased, and to a lesser extent at $24 \mathrm{~h}$ after morphine administration. Hence, part of the $\mu$ receptoractivated $\mathrm{G} \alpha \mathrm{z}$ proteins were retained by this regulator and thereby contributed to the development of acute morphine tolerance. Since RGSZ1 proteins showed little or no coprecipitation with $G \alpha z$ subunits, they probably only acted as GAPs when efficiently deactivating these subunits.

There is increasing evidence that RGS proteins exhibit regulatory properties that are not attributed to their GAP 
activity. The way that the distinct RGS proteins interact with $\mathrm{G} \alpha$ subunits has diverse regulatory consequences. While no RGS domain binds efficiently to the G $\alpha \mathrm{GDP}$ forms that cannot regulate effector proteins, RGS proteins of the RGSR4 and RGS-R7 subfamilies display greater affinity for GTP hydrolysis transition state than to the G $\alpha$ GTP form (Hunt et al, 1996; Berman et al, 1996; Posner et al, 1999). In contrast, the members of the RGS-Rz subfamily show the singular characteristic of binding with similar affinities to activated G $\alpha$ GTP and to the transition state (Wang et al, 1997). The extreme N-terminal helix of $\mathrm{G} \alpha$ subunits is crucial for its interaction with RGS-Rz proteins (Wang et al, 1998; Tu et al, 1997). This interaction does not occur between G $\alpha$ il and RGS4 (Tesmer et al, 1997) and could account for the binding of G $\alpha$ GTP to RGS-Rz proteins. In this scenario, the capacity of certain RGS proteins to bind to receptor-activated G $\alpha \mathrm{GTP}$ subunits could reduce $\mathrm{G} \alpha$ mediated activation of downstream effectors. The mechanism by which RGS proteins inhibit signaling pathways is termed effector antagonism and is found in different situations. In this respect, direct binding of RGS2, RGS3, RGS4, and GAIP to phospholipase $\mathrm{C} \beta 1$ interferes with activated $\mathrm{G} \alpha \mathrm{q}$ subunits (Hepler et al, 1997; Anger et al, 2004). Also, RGS2 and RGS 3 interact with adenylyl cyclases reducing cAMP production (Chatterjee et al, 1997; Sinnarajah et al, 2001). The direct association of RGS proteins with the intracellular domains of GPCRs could help to deactivate G $\alpha$ GTP subunits before they regulate their corresponding effectors. This has been documented for members of RGSR4 subfamily and subtypes of muscarinic acetylcholine receptors (Bernstein et al, 2004). In situations in which RGS proteins bind to $\mathrm{G} \alpha \mathrm{GTP}$ subunits but display little or no GAP activity on them, effector antagonism will occur. Sequestering of activated $\mathrm{G} \alpha \mathrm{q}$ subunits has been observed for the RGS domain of the kinase of GPCRs type 2 (GRK2), thereby interfering in the regulation of phospholipase $\mathrm{C} \beta$ (Carman et al, 1999). Similarly, sequestering of $\mathrm{G} \alpha$ subunits by RGS-R7 proteins reduces the effects mediated by $\mu$ receptors in the CNS (Garzón et al, 2005; Sánchez-Blázquez et al, 2003, 2005), while that of $\mathrm{G} \alpha \mathrm{q}$ by RGS-Rz proteins reduces calcium mobilization (Mao et al, 2004).

It has been reported that in mouse PAG, the administration of morphine in vivo induces the transfer of $\mu$ receptorassociated $\mathrm{G} \alpha$ subunits to RGS9-2 proteins (Garzón et al, 2005). Subsequently, the $G \alpha$ subunits are released from the RGS9-2 proteins and reassociate with the opioid receptors. However, doses of morphine able to induce tolerance promote the stable transfer of $\mathrm{G} \alpha$ subunits to RGS9-2 control, which appears to involve Ser phosphorylation of the RGS9-2 proteins and their binding to 14-3-3 proteins. The failure of the GTP $\gamma S$ form of $\mathrm{G} \alpha \mathrm{i} 2$ subunits to firmly attach to the RGSZ2 proteins suggests that following GAP activity, post-translational modifications of the RGS-Rz proteins and/or interactions with other proteins in neuronal membranes probably affect the RGSZ-G $\alpha$ GDP interaction surface. This promotes the sequestering of $\mathrm{G} \alpha$ subunits and therefore has profound regulatory consequences. In this respect, the RGS-Rz subfamily contains potential phosphorylation sites for PKC, casein kinase 2, and MAPK (de Vries et al, 1995; NetPhos 2.0 Prediction Server, Center for Biological Sequence Analysis). RGS-Rz proteins lack an asparagine that corresponds to position 128 in the RGS domain of the RGS4 protein (Tesmer et al, 1997). This is substituted by Ser179 in RGSZ1, Ser150 in RGSZ2, and Ser156 in GAIP (Tesmer et al, 1997; Posner et al, 1999). Moreover, the membrane-bound pool of GAIP is phosphorylated in the N-terminus (Fischer et al, 2000), and at Ser151 that lies inside the RGS domain (Ogier-Denis et al, 2000). The RGS-Rz subfamily binds with the dileucine-rich region of GIPN (GAIP interacting protein $\mathrm{N}$ terminus), a putative E3 ubiquitin ligase that links the RGS-Rz proteins with $\mathrm{G} \alpha$ degradation (Fischer et al, 2003). Since GPCR agonists can increase the rate of $\mathrm{G} \alpha$ subunit degradation (Levis and Bourne, 1992; Wise et al, 1995), the retention of $\mathrm{G} \alpha$ subunits by $\mathrm{RGS}-\mathrm{Rz}$ proteins might precede their degradation via the proteosome pathway. Interestingly, opioid tolerance produced by single doses lasts for several days, and novel synthesis of $\mathrm{G} \alpha$ subunits is required to restore the basal responses (Huidobro et al, 1976; Garzón et al, 2002). Post-translational modifications of the RGS-Rz proteins such as phosphorylation, glycosylation (Garzón et al, 2004; present work) and possibly dynamic palmitoylation-depalmitoylation of their N-terminal cysteine string ( 9 Cys residues out of 13), as well as interactions with other proteins could regulate their capacity to sequester $\mathrm{G} \alpha$ subunits.

Therefore, it is feasible that RGS-Rz proteins act as effector antagonists by sequestering $\mu$-opioid receptorregulated $\mathrm{G} \alpha \mathrm{i} / \mathrm{o} / \mathrm{z}$ subunits. This implies that $\mathrm{G} \alpha \mathrm{i} / \mathrm{o}$ subunits would compete with $\mathrm{G} \alpha \mathrm{z}$ subunits in their long-term association with RGSZ2 proteins or deactivation by RGSZ1 proteins (the later does not retain $\mathrm{G} \alpha \mathrm{z}$ subunits). Hence, the increased activation of $\mathrm{Gi} / \mathrm{o}$ proteins would bring about a greater activity of G $\alpha$ zGTP subunits at their effectors. Therefore, receptor desensitization would depend on the ratio of $\mathrm{Gi} / \mathrm{o} \alpha$ vs $\mathrm{Gz} \alpha$ subunits that are activated by a particular dose of a $\mu$ receptor agonist.

In solution assays, RGSZ1and RGSZ2 bind to activated $\mathrm{G} \alpha \mathrm{i} / \mathrm{o} / \mathrm{z} / \mathrm{q}$ subunits and with the exception of $\mathrm{G} \alpha \mathrm{q}$ subunits, display good GAP activity on them. They are also more

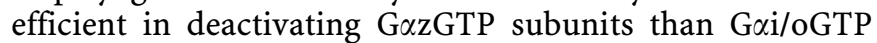
subunits, as is particularly evident for RGSZ1 proteins (see Mao et al (2004) and references therein). The G $\alpha$ zGTP subunits have a low intrinsic GTPase rate and thus RGSZ1 knockdown should prolong the period that G $\alpha$ ZGTP subunits act upon their effectors. In these circumstances, their deactivation would rely on other RGS proteins, for example, the RGS4 and RGS10 proteins (Berman et al, 1996; Hunt et al, 1996; Hepler et al, 1997). Similarly, while the potential of morphine and DAMGO to promote antinociception increases in the RGSZ1 knockdown mice, desensitization can be detected hours after their effects have ceased (Garzón et al, 2004). After RGSZ2 knockdown, significant and early increases in the effects of $\mu$ opioids were followed by rapid desensitization, particularly for morphine. Considering that RGSZ2 proteins might sequester G $\alpha$ subunits, RGSZ2 knockdown will greatly increase the activated $\mathrm{G} \alpha \mathrm{GTP}$ subunits that reach and regulate the effectors. The GAP activities of RGSZ1 and other RGS proteins probably now fail to efficiently control the regulation of the effectors exerted by these G $\alpha \mathrm{GTP}$ subunits (Figure 11). Thus, in these RGSZ2 knockdown mice, the increased activity of G $\alpha$ zGTP subunits at their effectors desensitizes the effects of the higher doses of morphine during its time-course. 
a
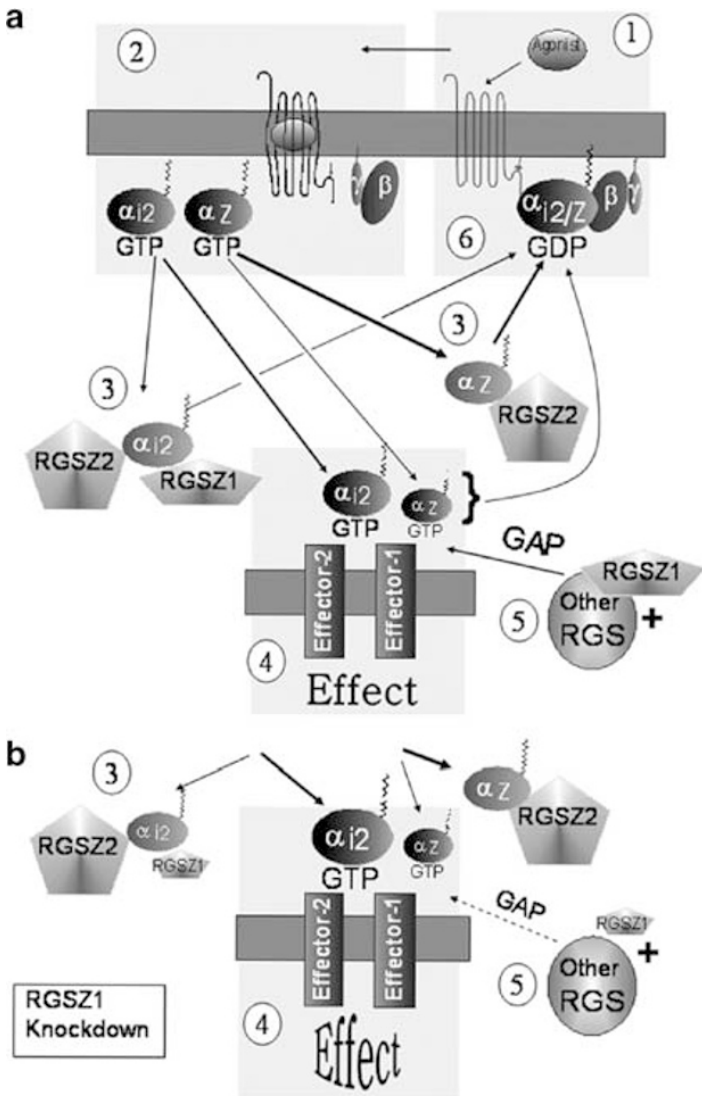

C

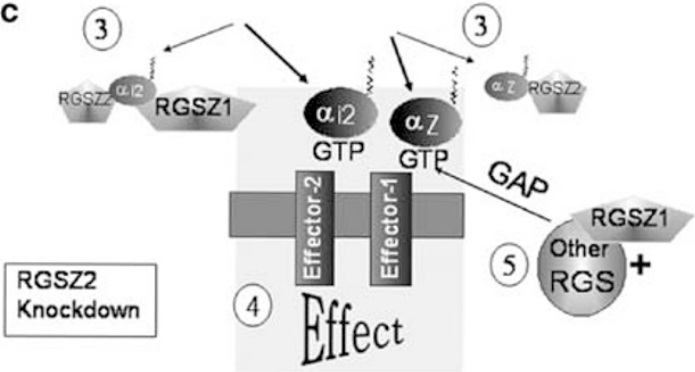

There is consistent evidence that RGS proteins show receptor selectivity. This has been reported for different RGS proteins in regulating $\mathrm{Gq}$ proteins activated by distinct receptors (Xu et al, 1999); RGS3 and muscarinic m3 receptor; RGS5 and angiotensin AT1a receptor (Wang et al, 2002); RGS8 towards muscarinic $\mathrm{m} 1$ and substance $\mathrm{P}$ receptors (Saitoh et al, 2002); RGS-R4 subfamily and subtypes of muscarinic acetylcholine receptors (Roy et al, 2003; Bernstein et al, 2004). In the present study, we show that both RGSZ1 and RGSZ2 co-precipitate with $\mu$-opioid receptors, and that the association between RGSZ and G $\alpha$ subunits is altered by a morphine challenge. Thus, in mouse brain synaptosomal membranes, these RGS-Rz proteins exist in a complex with $\mu$ receptors and control the agonisttriggered signals by interacting with $\mathrm{G} \alpha \mathrm{i} / \mathrm{o} / \mathrm{z}$ subunits and acting as effector antagonists.

\section{ACKNOWLEDGEMENTS}

We are indebted to Dr Brigitte L Kieffer (Institute of Genetics, Molecular and Cellular Biology, University Louis
Figure II Model of the role played by RGSZI and RGSZ2 proteins in regulating $\mu$-opioid receptor-activated $\mathrm{Gi} 2$ and $\mathrm{Gz}$ proteins. (a): (I) $\mu$ agonists bind with high affinity to receptors coupled to $\mathrm{G} i 2$ and $\mathrm{Gz}$ proteins. (2) They then promote the exchange of GTP for GDP at the G $\alpha$ subunits, and the activated $\mathrm{G} \alpha \mathrm{GTP}$ subunits segregate from $\mathrm{G} \beta \gamma$ dimers to reach the effectors. Since it is possible that $\mathrm{Gz} \alpha$ and $\mathrm{Gi} 2 \alpha$ subunits regulate different effectors (see Discussion), in the diagram we show GazGTP acting mostly on effector-1, while GoizGTP regulates both effectors I and 2. (3) A fraction of the RGSZI and RGSZ2 proteins bind Gai2 subunits preventing them from regulating activated G $\alpha z$ subunits. RGSZ2 also retains a substantial portion of $G \alpha z$ subunits for long intervals, which are probably deactivated and finally returned to reform the G $\alpha z G D P \beta \gamma$ heterotrimers (4) The outcome of these interactions is a depletion of the $\mu$ receptoractivated Goiz/zGTP subunits that could reach the effectors. (5) RGSZI and others RGS proteins (eg RGS4 and RGSI0) will deactivate GazGTP and Gai2GTP. (6) The GAP activity and the slow dissociation of RGS-Rztrapped Goir/z subunits will replenish the pool of G-proteins at the $\mu$ opioid receptor. Inefficient reconstitution will promote a reduced effect of the agonists. (b) Knockdown of RGSZI proteins diminishes the amount Gai2 subunits that are sequestered and more of these will now regulate the effectors I and 2. The reduced level of RGSZI protein affects the overall RGS GAP activity and thus, the activity of $\mu$ receptor-activated G $\alpha z /$ i2GTP subunits will increase at the effectors. In these circumstances, the effects of $\mu$ opioid agonists increase slowly during their time-course and desensitization, probably mediated by GazGTP on effector I, develops slowly. (c) Downregulation of RGSZ2 proteins permits a larger fraction of activated Gai2GTP and GazGTP subunits to reach and regulate the effectors. The RGS GAP activity now fails to efficiently control the increased G $\alpha z / i 2$ signaling. This regulation of the effectors is excessive and although the agonist's effects are greatly increased shortly after the opioid challenge, this is followed by a rapid desensitization. In this model, the increased regulatory activity of GazGTP at effector I facilitates agonist desensitization, while the effects of the agonists that are mediated by the action of G $\alpha i 2$ and/or other subunits at effector 2 persist, giving the plateau observed for the high doses of morphine (Figure 2). In this scheme, the capacity of a given agonist to produce receptor desensitization depends on the amount of activated $G \alpha z$ subunits that reach and regulates the effectors. The concurrent activation and sequestering of Gailo subunits by RGS-Rz proteins will favor desensitization to the agonist's effects promoted by $G \alpha z$ subunits.

Pasteur, Illkirch, France) for providing us with the C57BL/6 $\mu$-opioid receptor null $(-/-)$ mice. This work was supported by the SAF2003-01121, Instituto de Salud Carlos III G03/005 and MCYT BMC2002-03228.

\section{REFERENCES}

Anger T, Zhang W, Mende U (2004). Differential contribution of GTPase activation and effector antagonism to the inhibitory effect of RGS proteins on Gq-mediated signaling in vivo. J Biol Chem 279: 3906-3915.

Berman DM, Kozasa T, Gilman AG (1996). The GTPase-activating protein RGS4 stabilizes the transition state for nucleotide hydrolysis. J Biol Chem 271: 27209-27212.

Bernstein LS, Ramineni S, Hague C, Cladman W, Chidiac P, Levey AI et al (2004). RGS2 binds directly and selectively to the M1 muscarinic acetylcholine receptor third intracellular loop to modulate $\mathrm{Gq} / 11 \alpha$ signaling. J Biol Chem 279: 21248-21256.

Carman CV, Parent J-L, Day PW, Pronin AN, Sternweis PM, Wedegaertner PB et al (1999). Selective regulation of $\mathrm{G} \alpha \mathrm{q} / 11$ by an RGS domain in the G protein-coupled receptor kinase, GRK2. J Biol Chem 274: 34483-34492.

Carrasco GA, Barker SA, Zhang Y, Damjanoska KJ, Sullivan NR, Garcia F et al (2004). Estrogen treatment increases the levels of regulator of $\mathrm{G}$ protein signaling- $\mathrm{Z} 1$ in the hypothalamic paraventricular nucleus: possible role in desensitization of 5-hydroxytryptamine 1A receptors. Neuroscience 127: 261-267. 
Casey PJ, Fong HKW, Simon MI, Gilman AG (1990). Gz, a guanine nucleotide-binding protein with unique biochemical properties. J Biol Chem 265: 2383-2390.

Chatterjee TK, Eapen AK, Fisher RA (1997). A truncated form of RGS3 negatively regulates $G$ protein coupled receptor stimulation of adenylyl cyclase and phosphoinositide phospholipase C. J Biol Chem 272: 15481-15487.

De Vries L, Elenko E, Hubler L, Jones TL, Farquhar MG (1996). GAIP is membrane-anchored by palmitoylation and interacts with the activated (GTP-bound) form of G $\alpha$ i subunits. Proc Natl Acad. Sci USA 93: 15203-15208.

De Vries L, Lou X, Zhao G, Zheng B, Farquhar MG (1998). GIPC, a PDZ domain containing protein, interacts specifically with the $\mathrm{C}$ terminus of RGS-GAIP. Proc Natl Acad Sci USA 95: 12340-12345.

De Vries L, Mousli M, Wurmser A, Farquhar MG (1995). GAIP, a protein that specifically interacts with the trimeric $G$ protein $\mathrm{G} \alpha \mathrm{i} 3$, is a member of a protein family with a highly conserved core domain. Proc Natl Acad. Sci USA 92: 11916-11920.

Fischer T, De vries L, Meerlo T, Farquhar MG (2003). Promotion of $\mathrm{G} \alpha \mathrm{i} 3$ subunit down-regulation by GIPN, a putative E3 ubiquitin lugase that interacts with RGS-GAIP. Proc Natl Acad Sci USA 100: $8270-8275$.

Fischer T, Elenko E, Wan L, Thomas G, Farquhar MG (2000). Membrane-associated GAIP is a phosphoprotein and can be phosphorylated by clathrin-coated vesicles. Proc Natl Acad Sci USA 97: 4040-4045.

Fong HK, Yoshimoto KK, Eversole-Cire P, Simon MI (1988). Identification of a GTP-binding protein $\alpha$ subunit that lacks an apparent ADP-ribosylation site for pertussis toxin. Proc Natl Acad Sci USA 85: 3066-3070.

Garzón J, De Antonio I, Sánchez-Blázquez P (2000). In vivo modulation of $\mathrm{G}$ proteins and opioid receptor function by antisense oligodeoxynucleotides. Methods Enzymol 314: $3-20$.

Garzón J, García-España A, Sánchez-Blázquez P (1997a). Opioids binding mu and delta receptors exhibit diverse efficacy in the activation of $\mathrm{Gi} 2$ and $\mathrm{Gx} / \mathrm{z}$ transducer proteins in mouse periaqueductal gray matter. $J$ Pharmacol Exp Ther 281: 549-557.

Garzón J, Juarros JL, Castro MA, Sánchez-Blázquez P (1995). Antibodies to the cloned $\mu$-opioid receptor detect various molecular weight forms in areas of mouse brain. Mol Pharmacol 47: 738-744.

Garzón J, López-Fando A, Sánchez-Blázquez P (2003). The R7 subfamily of RGS proteins assists tachyphylaxis and acute tolerance at $\mu$-opioid receptors. Neuropsychopharmacology 28: 1983-1990.

Garzón J, Martínez-Peña Y, Sánchez-Blázquez P (1997b). Gx/z is regulated by $\mu$ but not $\delta$ opioid receptors in the stimulation of the low Km GTPase activity in mouse periaqueductal grey matter. Eur J Neurosci 9: 1194-1200.

Garzón J, Rodríguez-Díaz M, López-Fando A, García-España A, Sánchez-Blázquez P (2002). Glycosylated phosducin-like protein long regulates opioid receptor function in mouse brain. Neuropharmacology 42: 813-828.

Garzón J, Rodríguez-Muñoz M, López-Fando A, García-España A, Sánchez-Blázquez P (2004). RGSZ1 and GAIP regulate $\mu$-but not $\delta$-opioid receptors in mouse CNS: role in tachyphylaxis and acute tolerance. Neuropsychopharmacology 29: 1091-1104.

Garzón J, Rodríguez-Díaz M, López-Fando A, Sánchez-Blázquez $\mathrm{P}$ (2001). RGS9 proteins facilitate acute tolerance to mu-opioid effects. Eur J Neurosci 13: 801-811.

Garzón J, Rodríguez-Muñoz M, López-Fando A, Sánchez-Blázquez $P$ (2005). Activation of mu-opioid receptors transfer control of $\mathrm{G} \alpha$ subunits to the regulator of G-protein signaling RGS9-2. Role in receptor desensitization. J Biol Chem 280: 8951-8960.

Glick JL, Meigs TE, Miron A, Casey PJ (1998). RGSZ1, a Gzselective regulator of $G$ protein signaling whose action is sensitive to the phosphorylation state of Gza. J Biol Chem 273: 26008-26013.

Hall A, Self AJ (1986). The effect of $\mathrm{Mg}^{2+}$ on the guanine nucleotide exchange rate of p21N-ras. J Biol Chem 261: 10963-10965.

Hallak H, Muszbek L, Laposata M, Belmonte E, Brass LF, Manning DR (1994). Covalent binding of arachidonate to G protein alpha subunits of human platelets. J Biol Chem 269: 4713-4716.

Hepler JR, Berman DM, Gilman AG, Kozasa T (1997). RGS4 and GAIP are GTPase-activating proteins for $\mathrm{Gq} \alpha$ and block activation of phospholipase C $\beta$ by $\gamma$-thio-GTP-Gq $\alpha$. Proc Natl Acad Sci USA 94: 428-432.

Hinton DR, Blanks JC, Fong HK, Casey PJ, Hildebrandt E, Simons MI (1990). Novel localization of a $G$ protein, G $\alpha$ z, in neurons of brain and retina. J Neurosci 10: 2763-2770.

Ho MK, Chang JS, Yung LY, Wong YH (2000). The effect of protein kinase $\mathrm{C}$ activation on $\mathrm{Gz}$-mediated regulation of type 2 and type 6 adenylyl cyclases. Biol Signal Recept 9: 21-28.

Huidobro F, Huidobro-Toro JP, Way EL (1976). Studies on tolerance development to single doses of morphine in mice. J Pharmacol Exp Ther 198: 318-326.

Hunt TW, Fields TA, Casey PJ, Peralta EG (1996). RGS10 is a selective activator of G $\alpha$ i GTPase activity. Nature 383: 175-177.

Ito E, Xie G, Maruyama K, Palmer PP (2000). A core-promoter region functions bi-directionally for human opioid-receptor-like gene ORL1 and its 5'-adjacent gene GAIP. J Mol Biol 304: 259-270.

Jeong SW, Ikeda SR (1998). G protein $\alpha$ subunit G $\alpha$ z couples neurotransmitter receptors to ion channels in sympathetic neurons. Neuron 21: 1201-1212.

Jordan JD, Carey KD, Stork PJS, Iyengar R (1999). Modulation of Rap activity by direct interaction of G $\alpha$ o with Rap1 GTPaseactivating protein. J Biol Chem 274: 21507-21510.

Kohno M, Fukushima N, Yoshida A, Ueda H (2000). Gil and GoA differentially determine kinetic efficacies of agonists for $\kappa$-opioid receptor. FEBS Lett 473: 101-105.

Levis MJ, Bourne HR (1992). Activation of the $\alpha$ subunit of Gs in intact cells alters its abundance, rate of degradation, and membrane avidity. J Cell Biol 119: 1297-1307.

Lounsbury KM, Casey PJ, Brass LF, Manning DR (1991). Phosphorylation of $\mathrm{Gz}$ in human platelets. Selectivity and site of modification. J Biol Chem 266: 22051-22056.

Mao H, Zhao Q, Daigle M, Ghahremani MH, Chidiac P, Albert PR (2004). RGS17/RGSZ2, a novel regulator of Gi/o, Gz and Gq signaling. J Biol Chem 279: 26314-26322.

Mumby SM, Heukeroth RO, Gordon JI, Gilman AG (1990). Gprotein alpha-subunit expression, myristoylation, and membrane association in COS cells. Proc Natl Acad Sci USA 87: $728-732$

Ogier-Denis E, Pattingre S, El Benna J, Codogno P (2000). Erk1/2dependent phosphorylation of $\mathrm{G} \alpha$-interacting protein stimulates its GTPase accelerating activity and autophagy in human colon cancer cells. J Biol Chem 275: 39090-39095.

Posner BA, Gilman AG, Harris BA (1999). Regulators of G protein signaling 6 and 7. Purification of complexes with $G \beta 5$ and assessment of their effects on $G$ protein-mediated signaling pathways. J Biol Chem 274: 31087-31093.

Ross EM, Wilkie TM (2000). GTPase-activating proteins for heterotrimeric $G$ proteins: regulators of $G$ protein signaling (RGS) and RGS-like proteins. Ann Rev Biochem 69: 795-827.

Roy AN, Lemberg KE, Chidiac P (2003). Recruitment of RGS2 and RGS4 to the plasma membrane by G proteins and receptors reflects functional interactions. Mol Pharmacol 64: 587-593.

Saitoh O, Murata Y, Osagiri M, Itoh M, Itoh $\mathrm{H}$, Misaka $\mathrm{T}$ et al (2002). Alternative splicing of RGS8 gene determines inhibitory function of receptor type-specific Gq signaling. Proc Natl Acad Sci USA 99: 10138-10143.

Sánchez-Blázquez P, García-España A, Garzón J (1995). In vivo injection of antisense oligodeoxynucleotides to $\mathrm{G} \alpha$ subunits and 
supraspinal analgesia evoked by mu and delta opioid agonists. J Pharmacol Exp Ther 275: 1590-1596.

Sánchez-Blázquez P, Gómez-Serranillos P, Garzón J (2001). Agonists determine the pattern of G-protein activation in $\mu$ opioid receptor-mediated supraspinal analgesia. Brain Res Bull 54: 229-235.

Sánchez-Blázquez P, Rodríguez-Díaz M, De Antonio I, Garzón J (1999). Endomorphin-1 and endomorphin-2 show differences in their activation of $\mu$ opioid receptor-regulated G proteins in supraspinal antinociception in mice. J Pharmacol Exp Ther 291: 12-18.

Sánchez-Blázquez P, Rodríguez-Díaz M, López-Fando A, Rodríguez-Muñoz M, Garzón J (2003). The GBeta5 subunit that associates with the R7 subfamily of RGS proteins regulates muopioid effects. Neuropharmacology 45: 85-98.

Sánchez-Blázquez P, Rodríguez-Muñoz M, Montero C, Garzón J (2005). RGS-Rz and RGS9-2 proteins control mu-opioid receptor desensitization in CNS: the role of activated G $\alpha$ z subunits. Neuropharmacology 48: 134-150.

Sierra DA, Gilbert DJ, Householder D, Grishin NV, Yu K, Ukidwe P et al (2002). Evolution of the regulators of G-protein signaling multigene family in mouse and human. Genomics 79: 177-185.

Sinnarajah S, Dessauer CW, Srikumar D, Chen J, Yuen J, Yilma S et al (2001). RGS2 regulates signal transduction in olfactory neurons by attenuating activation of adenylyl cyclase III. Nature 409: 1051-1055.

Standifer KM, Rossi GC, Pasternak GW (1996). Differential blockade of opioid analgesia by antisense oligodeoxynucleotides directed against various $G$ protein $\alpha$ subunits. Mol Pharmacol 50: 293-298.

Tesmer JJ, Berman DM, Gilman AG, Sprang SR (1997). Structure of RGS4 bound to AlF4-activated Gi $\alpha 1$ : stabilization of the transition state for GTP hydrolysis. Cell 89: 251-261.
Tu Y, Wang J, Ross Em (1997). Inhibition of brain Gz GAP and other RGS proteins by palmitoylation of $\mathrm{G}$ protein $\alpha$ subunits. Science 278: 1132-1135.

Wang J, Ducret A, Tu Y, Kozasa T, Aebersold R, Ross EM (1998). RGSZ1, a Gz-selective RGS protein in brain. J Biol Chem 273: 26014-26025.

Wang J, Tu Y, Woodson J, Song X, Ross EM (1997). A GTPaseactivating protein for the G protein G $\alpha$ z. J Biol Chem 272: 5732 5740.

Wang Q, Liu M, Mullah B, Siderovski DP, Neubig RR (2002). Receptor-selective effects of endogenous RGS3 and RGS5 to regulate mitogen-activated protein kinase activation in rat vascular muscle cells. J Biol Chem 277: 24949-24958.

Wise A, Lee TW, McEwan DJ, Milligan G (1995). Degradation of $\mathrm{G} 11 \alpha / \mathrm{Gq} \alpha$ is accelerated by agonist occupancy of $\alpha 1 \mathrm{~A} / \mathrm{D}, \alpha 1 \mathrm{~B}$, and $\alpha 1 \mathrm{C}$ adrenergic receptors. J Biol Chem 270: 17196-17203.

Wong YH, Conklin BR, Bourne HR (1992). Gz-mediated hormonal inhibition of cyclic AMP accumulation. Science 255: 339-342.

Xu X, Zeng W, Popov S, Berman DM, Davignon I, Yu K et al (1999). RGS proteins determine signaling specificity of Gq-coupled receptors. J Biol Chem 274: 3549-3556.

Yaksh TL, Yeung JC, Rudy TA (1976). Systematic examination in the rat of brain sites sensitive to the direct application of morphine: observation of differential effects within the periaqueductal grey. Brain Res 114: 83-103.

Zaworski PG, Alberts GL, Pregenzer JF, Im WB, Slightom JL, Gill GS (1999). Efficient functional coupling of the human D3 dopamine receptor to Go subtype of $\mathrm{G}$ proteins in SH-SY5Y cells. Br J Pharmacol 128: 1181-1188. 